\title{
PETROLOGY OF THE ULTRA-HIGH PRESSURE METAMORPHIC KIMI COMPLEX IN RHODOPE (N.E. GREECE): A NEW INSIGHT INTO THE ALPINE GEODYNAMIC EVOLUTION OF THE RHODOPE

\author{
E.MPOSKOS ${ }^{1}$
}

\begin{abstract}
Structural, petrological and geochronological work has revealed that the Rhodope metamorphic province is a synmetamorphic nappe-system of Alpine age. The Kimi complex representing the uppermost entity underwent UHP metamorphism in Lower Cretaceous ( $\geq 119 \mathrm{Ma}$ ). Diamond inclusions in garnet porphyroblasts, exsolutions of quartz rods and rutile needles in garnet from Grt-Ky-Bt-gneisses constrain pressures $>4 \mathrm{GPa}$ (probably $\sim 7 \mathrm{GPa}$ ) and temperatures $>1000^{\circ} \mathrm{C}$, indicating subduction of continental crust into the asthenospheric mantle.

The garnet-spinel peridotite of the Kimi area represents a segment of upwelling asthenosphere reequilibrated into the lithospheric mantle wedge at $\sim 2.5 \mathrm{GPa}$ and $1235^{\circ} \mathrm{C}$. The spinel-garnet clinopyroxenites, associated with the peridotite, represent HP mantle cumulates crystallized from a melt at similar P-T conditions (i.e. P $2.4 \mathrm{GPa}$, $\mathrm{T} \sim 1200^{\circ} \mathrm{C}$ ). Decompression and cooling took place in the mantle wedge within the Cr-Spinel peridotite field up to $\sim 1.8 \mathrm{GPa}$ and $900^{\circ} \mathrm{C}$. Subsequent isobaric cooling crossed the stability field of garnet peridotite. At this stage, the peridotite was tectonically emplaced into the educted underlying continental crust. Three stages of exhumation of the crustal assemblage occurred in the Kimi Complex. The first stage, from the maximum depth of $\sim 200-$ $220 \mathrm{Km}$ to $\sim 60 \mathrm{Km}\left(\mathrm{P} \sim 1.6 \mathrm{GPa}, \mathrm{T} \sim 800{ }^{\circ} \mathrm{C}\right)$, is characterized by slow cooling rates, indicating rapid exhumation. The second stage, from $\sim 60 \mathrm{Km}$ to $-38 \mathrm{Km}\left(\mathrm{P} \sim 1.05 \mathrm{GPa}, \mathrm{T} \sim 640^{\circ} \mathrm{C}\right)$, is indicated by cooling at slow rates and is characterized by hydration and annealing reequilibration/recrystallization processes. The third stage of exhumation started between 73 and $65 \mathrm{Ma}$ and is characterized by rapid uplift, continuous influx of water, intrusion of muscovite pegmatites at $\sim 20 \mathrm{Km}$ depth, and finally by rapid cooling at shallow levels. The Kimi Complex reached the surface before $48-42 \mathrm{Ma}$.
\end{abstract}

\section{INTRODUCTION}

The discovery of coesite (Smith 1984) and microdiamonds (Sobolev and Shatsky, 1990) in ultra-high pressure (UHP) crustal rocks has revolutionized our understanding of continental collision zones and mantle dynamics attending subduction. The realization that segments of continental and oceanic crust have returned to the surface from depths of $100 \mathrm{~km}$ or more, is in itself, remarkable. UHP rocks record a complete geodynamic pathway and represent constraints for testing hypotheses of crust/mantle interactions, and mechanisms combining subduction and tectonic exhumation.

Liou et al. (1998) defined UHP metamorphism as mineralogical and structural readjustment of supracrustal rocks and associated ultramafic slices at pressures greater than $\sim 2.5 \mathrm{GPa}(\sim 80-90 \mathrm{Km})$. In cases of appropriate bulk chemistry, metamorphism at great depths produces coesite, microdiamond, and/or other characteristic UHP minerals.

Coesite is known from at least 10 genetically distinct orogenic belts (Liou et al., 1998). It is most often found in eclogite blocks or layers within the continental rocks, as inclusions within other minerals, or as a rare intergranular phase, but it also occurs as inclusions in zircons within the continental rocks themselves. Diamond is reported as included phase in graphitic biotite schists and gneisses and dolomitic marbles from four orogenic belts including the Kokchetav terrane in Kazakhstan (Sobolev and Shatsky, 1990). Dabie Shan-Sulu UHP terrane China (Xu et al., 1992), the Western Gneiss Region of Norway (Dobrzhinestkaya et al., 1995) and the Saxonian Erzgebirge in Germany (Massonne, 1998). The new discovery of diamond inclusions in garnet porphyroblasts from pelitic gneisses from the Rhodope metamorphic province (RMP), N.E. Greece, (Mposkos et al., 2001,

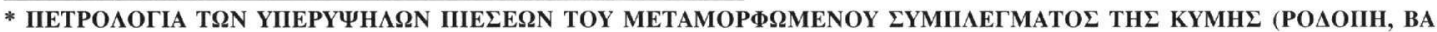

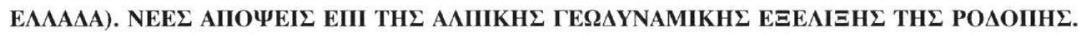

${ }^{1}$ Dr. Mposkos, National Technical University of Athens, Department of Mining and Metallurgical Engineering, Section of Geological Sciences, 9 Heroon Polytechniou, 15780, Zografou, Athens, Greece, e-mail: mposkos@metal.ntua.gr
} 
Mposkos \& Kostopoulos, 2001) makes the latter the fifth known diamond bearing UHP metamorphic belt of the world. Moreover, graphitised diamonds are reported from amphibolitized eclogite, tectonically intruded into the Circum Rhodope zone south of Thessaloniki in Central Macedonia (Kostopoulos et. al., 2000).

Temperatures of eclogites during UHP metamorphism, assessed mostly via Fe-Mg exchange between garnet and clinopyroxene or phengite, range from $\sim 700^{\circ} \mathrm{C}$ to $900^{\circ} \mathrm{C}$. At these temperatures, the presence of diamond constrains the minimum metamorphic pressure to $>3.5-4.0 \mathrm{GPa}$, corresponding to depths of $\sim 110-130 \mathrm{Km}$ (Liou et al., 1998).

Garnet-bearing ultramafic rocks (GBU) are volumetrically minor components in many HP/UHP terranes of orogenic belts but they represent valuable witnesses of geodynamic processes. They occur as few to numerous lensoid masses, normally within the continental HP/UHP rocks. GBU consist of a variety of rock types, predominantly garnet peridotites, which are commonly cut by veins of garnet pyroxenite and in some cases by eclogite. The peridotites are interpreted as residual mantle material from which basaltic melts were extracted (Brueckner \& Medaris, 2000). The pyroxenites and eclogites are believed in many cases to be high-pressure crystal cumulates from melts that invaded the peridotites while deep in the mantle (Becker, 1996). In general the GBU lenses in gneiss terranes record the emplacement of mantle material into the continental crust and reveal the composition of the upper mantle and the nature of mantle/crust interaction processes. Two main hypotheses, both involving continent-continent collision, have been proposed to explain the occurrence of GBU in such crustal sequences: (1) GBU were tectonically emplaced from the mantle wedge into thickened crust ("mantle" peridotite) and (2) GBU were produced by prograde HP/UHP metamorphism of peridotites or their serpentinized equivalents which previously had been emplaced into the crust ("crustal" peridotite, Brueckner \& Medaris, 2000).

The Rhodope metamorphic province is the only known Alpine UHP terrane in East Mediterranean and offers a unique opportunity to investigate UHP metamorphic processes and related mantle/crust interactions.

In this article are presented: i) the recently discovered UHP indicators from crustal rocks of the Alpine UHP metamorphic Kimi Complex in Rhodope, ii) the mantle derived garnet-spinel peridotites and garnet clinopyroxenites, tectonically emplaced into the crustal assemblage, and iii) their common exhumation history to the surface. P-T-t exhumation trajectories are constructed based on mineral assemblages, textural relations, and mineral chemistry of appropriate rock types and the available geochronological data. Based on the petrological data it will be demonstrated that the ultramafic rocks are tectonically emplaced into the Kimi UHP crustal assemblage from the overlaying mantle wedge during exhumation.

\section{GEOLOGICAL BACKGROUND AND FIELD RELATIONS}

The Rhodope metamorphic province (RMP) is one of the major geotectonic units of northern Greece. It has been traditionally viewed as a stable continental block, consolidated in Precambrian to Palaeozoic times. Recent structural and petrological work has nevertheless shown the RMP in fact to be a complex of Alpine synmetamorphic nappe complexes characterized by south - to southwestward stacking and associated with both coeval and subsequent extension in an Alpine active margin setting (Ricou et al., 1988; Wawrzenitz \& Krohe 1998; Dinter, 1998, Barr et al., 1999; Mposkos \& Krohe, 2000).

Mposkos and Krohe (2000) and Krohe and Mposkos (2001) have further subdivided the RMP into discrete entities on the basis of calculated metamorphic P-T paths and exhumation age criteria for the various metamorphic rocks. Thus, the earliest exhumed and structurally uppermost entity is the Kimi Complex (65-48 Ma), followed by the Sidironeron (Central Rhodope) and Kechros (East Rhodope) Complexes (42-30 Ma) and then by the Pangaeon Complex (26-8 Ma), which also forms the well-defined Rhodope metamorphic core complex. In terms of metamorphic P-T paths the major difference between the structurally lower complexes (i.e. Pangaeon, lower Sidironeron [Albite-Gneiss Series] and Kechros) and the overlying (upper Sidironeron and Kimi) is that in the latter prograde assemblages developed at $\mathrm{T}>550^{\circ} \mathrm{C}$, whereas in the former they developed at $\mathrm{T}<550^{\circ} \mathrm{C}$. Available peak pressure estimates range from ca 0.9GPa for Pangaeon, to about 1.5 for Kechros and $1.9 \mathrm{GPa}$ for upper Sidironeron. The new discovery of multicrystalline polygonal quartz aggregates (MPQ), pseudomorphic after coesite in eclogitic garnet, minute carbon cubes and octahedra (diamonds) included in garnet porphyroblasts, and especially of rods (or needles) of silica, rutile and apatite exsolved inside sodic garnet porphyroblasts from Grt-Bt-Ky-gneisses (abbreviations after Bucher and Frey, 1994), from the Kimi and a part of the upper Sidironeron complex document an UHP event for the Kimi Complex with peak pressure >4 GPa (Mposkos and Kostopoulos, 2001). 


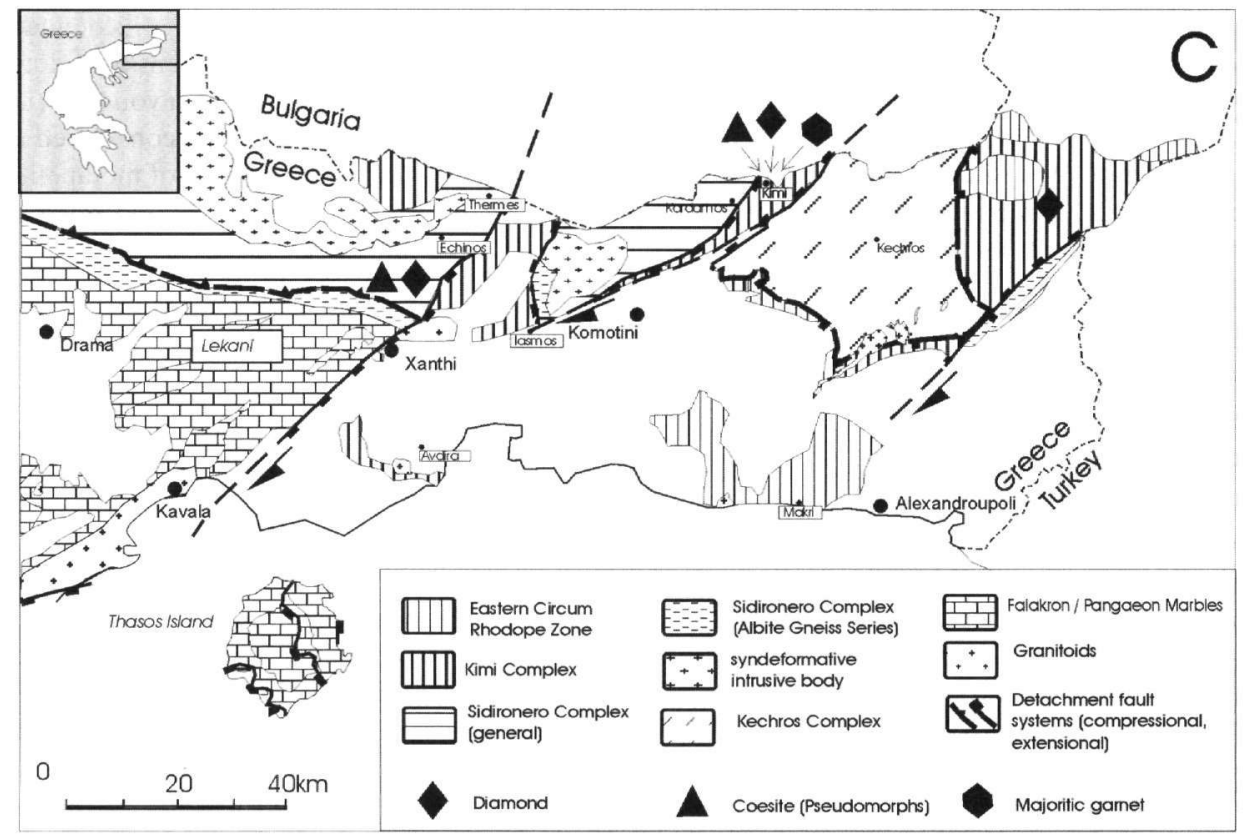

Figure 1: Geological map of central and eastern Rhodope (after Mposkos \& Krohe, 2000, simplified) with locations of samples containing diamond, coesite and supersilicic garnet.

The UHP Kimi complex consists of continental crust and mantle rocks. Predominant are migmatic quartzfeldspar gneisses, kyanite-bearing pelitic gneisses and marbles that host large boudins of amphibolites, eclogiteamphibolites, tonalitic to granitic metaplutons as well as an ultramafic association mostly made up by mantle lherzolites (Mposkos, 1994). Widespread pegmatites intersect the lithological succession. An Sm-Nd garnetclinopyroxene-whole rock age of $119 \mathrm{Ma}$ from a spinel-garnet-pyroxenite, associated with the garnet-spinel peridotite, is interpreted as the age of high-P/high-T metamorphism $\left(\sim 1.6 \mathrm{GPa}\right.$ at $\sim 770^{\circ} \mathrm{C}$, Wawrzenitz and Mposkos, 1997). An Rb-Sr age of 65 Ma of an undeformed muscovite from a pegmatite is interpreted as crystallization (thus intrusion) age at amphibolite facies conditions rather than as cooling age (Mposkos and Wawrzenitz, 1995). Ages, constraining the peak of the UHP event are still not available from the Kimi area. SHRIMP U-Pb ages of metamorphic rims of detrital zircons from Grt-Ky-Bt-gneisses and partially amphibolitized eclogites from Central-Rhodope (Pilima and Siroco areas) are in the range 148-138 Ma (Gebauer and Liati, 1997; Liati and Gebauer, 2001). In these rocks inclusions of MPQ aggregates pseudomorphic after coesite, are found in garnets from amphibolitized eclogite as well as inclusions of microdiamonds in garnet porphyroblasts from the Grt-Ky-Bt-gneisses (Mposkos and Kostopoulos, 2001; Mposkos et al., 2001). These UHP indicators, document that the upper Sidironeron Complex (at least in the Xanthi-Pilima area) contains slices of rock associations that underwent the UHP metamorphism evident in the overlying Kimi Complex. The zircon ages of 148-138 Ma could possibly record the time of a stage of the prograde path and the peak of the UHP event, if we assume that the Sm-Nd Grt-Cpx-whole rock age of $119 \mathrm{Ma}$ from the Kimi pyroxenite represents a recrystallization age of the UHP event. However, the dated detrital zircons show lead loss due to a younger metamorphic event (Liati \& Gebauer, 2001). It is possible that the dated rims of the detrital zircons formed in pre-Alpine event(s) and the ages of 148-138 Ma probably have no geological significance.

Characteristically, the Kimi Complex is only a few hundreds of meters thick and tectonically sandwiched between complexes showing totally different metamorphic histories. In the hanging wall the Kimi Complex is immediately overlain by the similarly thin circum Rhodope zone (CRZ). This comprises unmetamorphosed Jurassic ophiolite sequences showing K-Ar hornblende formation ages and apatite fission track ages at ca. 150160 Ma (Tsikouras et al., 1990; Bigazzi et al., 1989) and phyllites and marbles metamorphosed at temperatures lower than ca. $400^{\circ} \mathrm{C}$ (chlorite zone). Lutetian transgression at ca. $48 \mathrm{Ma}$ upon both the Kimi Complex and the CRZ indicates that juxtaposition of these two complexes and denudation of the UHP Kimi Complex was before 
$48 \mathrm{Ma}$. This also shows that the Kimi Complex became the site of subsidence very soon after its denudation. In the footwall, the Kimi Complex is separated by Late Eocene to the Oligocene discrete extensional detachment surfaces (Krohe \& Mposkos, 2001, Fig. 1) from tectonic complexes that experienced much younger (i.e. Tertiary) metamorphic histories, including Tertiary high-P metamorphism. Such complexes are considered as pieces of the Apulian plate (Mposkos and Krohe, 2000; Krohe and Mposkos, 2001). They consist of metapelites, thick marble assemblages, mafic assemblages as well as Variscan crust including orthogneisses and migmatites reworked during Alpine metamorphism.

\section{PETROGRAPHY AND MINERAL CHEMISTRY}

\subsection{UHP indicators}

In both, the Kimi and the Sidironeron Complexes, indicator minerals for UHP metamorphism occur in pelitic garnet-kyanite-staurolite-chlorite schists, garnet-kyanite-biotite gneisses and amphibolitized eclogites. In the Kimi Complex these include: (I) MPQ aggregates pseudomorphic after coesite included in garnet from amphibolitized eclogites. Strong sub-radial cracks emanate from the inclusions (Plate 1A), (II) exsolution lamellae of quartz in eclogite clinopyroxene indicating a precursor of supersilicic clinopyroxene (Plate 1B). (III) minute carbon cubes and octahedra of partially or completely graphitised diamonds included in garnet porphyroblasts (Plate 1D) from Grt-Ky-Bt-gneisses and Grt-Ky-St-Chl-schists. They were initially identified optically and subsequently verified by both EMP analysis (pure carbon) and in situ laser Raman microspectroscopy (Mposkos et al. 2001, Mposkos and Kostopoulos 2001). (IV) rods (or needles) of silica, rutile and apatite and biotite flakes exsolved inside sodic garnet porphyroblasts in Grt-Ky-Bt-gneisses (Plate 1E, F). Similar exsolution textures (i.e. clinopyroxene, rutile, and apatite exsolution rods in garnet) have been reported for eclogites from Yangkou, Sulu UHP metamorphic province in China (Ye et al., 2000). The exsolution of quartz, rutile, and apatite is taken as indicative of the existence of a garnet precursor phase richer than normal in $\mathrm{Si}, \mathrm{Ti}$ and $\mathrm{P}$, that is a supersilicic garnet (Collerson et al. 2000). In the Sidironeron Complex (Pilima area) indicator minerals for UHP metamorphism also comprise (I) MPQ aggregates included in garnet from amphibolitized eclogite, (II) inclusions of minute carbon cubes and octahedra in garnet from Grt-Ky-Bt-gneisses, and (III) rutile needles and biotite flakes exsolved inside garnet porphyroblasts.

The presence of MPQ aggregates as inclusions in porphyroblastic garnet from amphibolitized eclogites is attributed to the breakdown of pre-existing coesite and constrains metamorphic pressures to a minimum of 2.73.0 GPa at $700-1000^{\circ} \mathrm{C}$ (Hemingway et al. 1998). The exsolution lamellae of quartz in eclogitic clinopyroxene are also indicative of ultrahigh-pressure metamorphism. Moreover, the mere presence of diamonds in garnet from metapelites dictates metamorphic pressures in excess of 3.5-4.5 GPa at $700-1000^{\circ} \mathrm{C}$ (Chatterjee et al. 1998) for the host rocks. Thus, at the first approximation, minimum depths of $85-140 \mathrm{Km}$ for the subduction of the crustal protoliths of the Kimi Complex may be inferred by using only mineralogical criteria.

\subsection{Ultramafic association}

Near Kimi village (Fig.1), an ultramafic association occurs as a group of boudins that reach lengths of up to several kilometres. This association typically consists of garnet-spinel-bearing lherzolites that locally alternate with layers of spinel-garnet clinopyroxenite, garnet clinopyroxenite, olivine clinopyroxenite and clinopyroxene garnetite.

\subsection{Garnet-spinel peridotite}

The peridotite shows macroscopically a distinct foliation, which is defined by flattening (stretching) of older clino- and orthopyroxene porphyroclastic grains and recrystallized grain aggregates; the latter formed in a postdeformational static annealing stage.

The mineral assemblage of the garnet-spinel peridotite is Ol-Opx-Cpx-Grt-Hbl-Spl (chromian). Garnet is rarely observed as inclusions in olivine, orthopyroxene, clinopyroxene and hornblende.

Various spinel generations can be distinguished on textural and chemical criteria. Large Cr-rich crystals show compositional zoning (Plate $2 \mathrm{~A}$ ) with decreasing $\mathrm{Cr} /(\mathrm{Cr}+\mathrm{Al})$ ratios and increasing $\mathrm{Mg} /(\mathrm{Mg}+\mathrm{Fe})$ ratios from the core to the rim, (Fig.2). The core (Spl1) composition with a $\mathrm{Cr} /(\mathrm{Cr}+\mathrm{Al}$ ) ratio $\sim 0.44-0.48$ and a $\mathrm{Mg} /$ $(\mathrm{Mg}+\mathrm{Fe})$ ratio $\sim 0.50-0.58$ depicts the maximum preserved P-T conditions within the stability field of the spinel peridotite. Toward the rim the $\mathrm{Cr} /(\mathrm{Cr}+\mathrm{Al})$ ratios successively decrease to $\sim .22-0.15$. This is in general agreement with spinel growth at the expense of Al-bearing pyroxenes and presumably garnet with decreasing tem- 

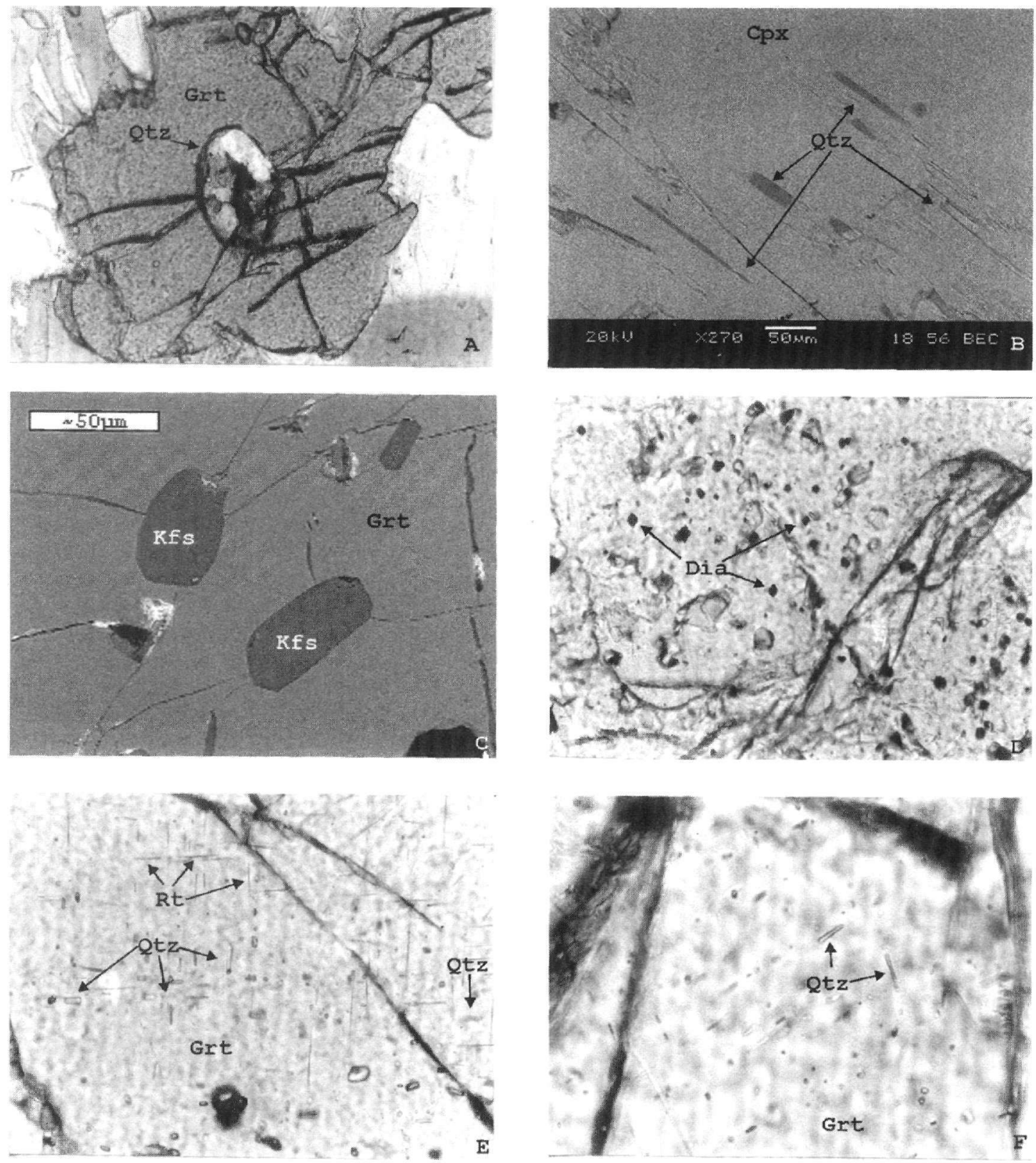

\section{Plate 1: UHP Indicators:}

A: Dnotonicrograoh of muiticrystiline polygonai quarz ivPQ! aggregatos pseudomonoic aftér cossito, included in garnet from ampribolitized eclogize. Note the radid fracuring of the gamet host. Fieldo= view 2 . Gm, crossed polara. B: Sil image of exsolition lamel. lae of juartzir clinopyroxene from eclogizo. C: SEM image of K-folspar inclis ons ir garrec. Racial fractures of rost gaznot emanato from tre r.clusions. D: protomicrograph oE inclusions of gzaphitized ricrocianonds ir garmez porphrojase from. Srt-ky-E: gneiss are crt-Ky-St-Cl: schist. Some of the diamoncis sacw wel- doveloged octaredral crystal faces. Fiejd of view a 3 m, poiarizer or

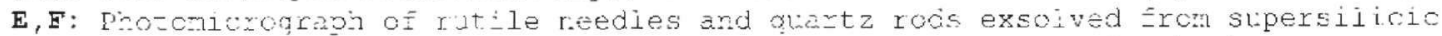
garrez. Note the preferred orientation of tre exsolved pheses ir: lire host garnet. Gr -3i-ky gness. Field of view C. $4 \mathrm{~mm}$, polarizer onlv. 

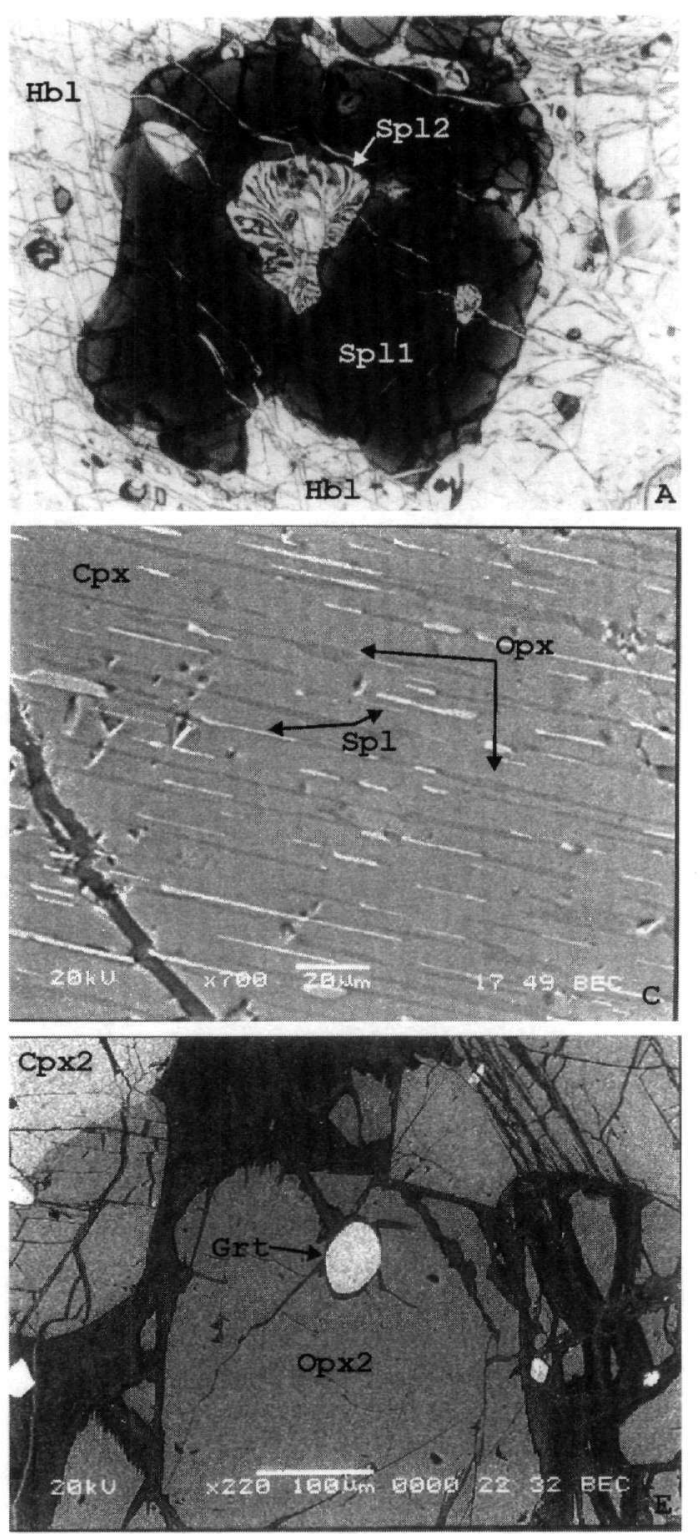
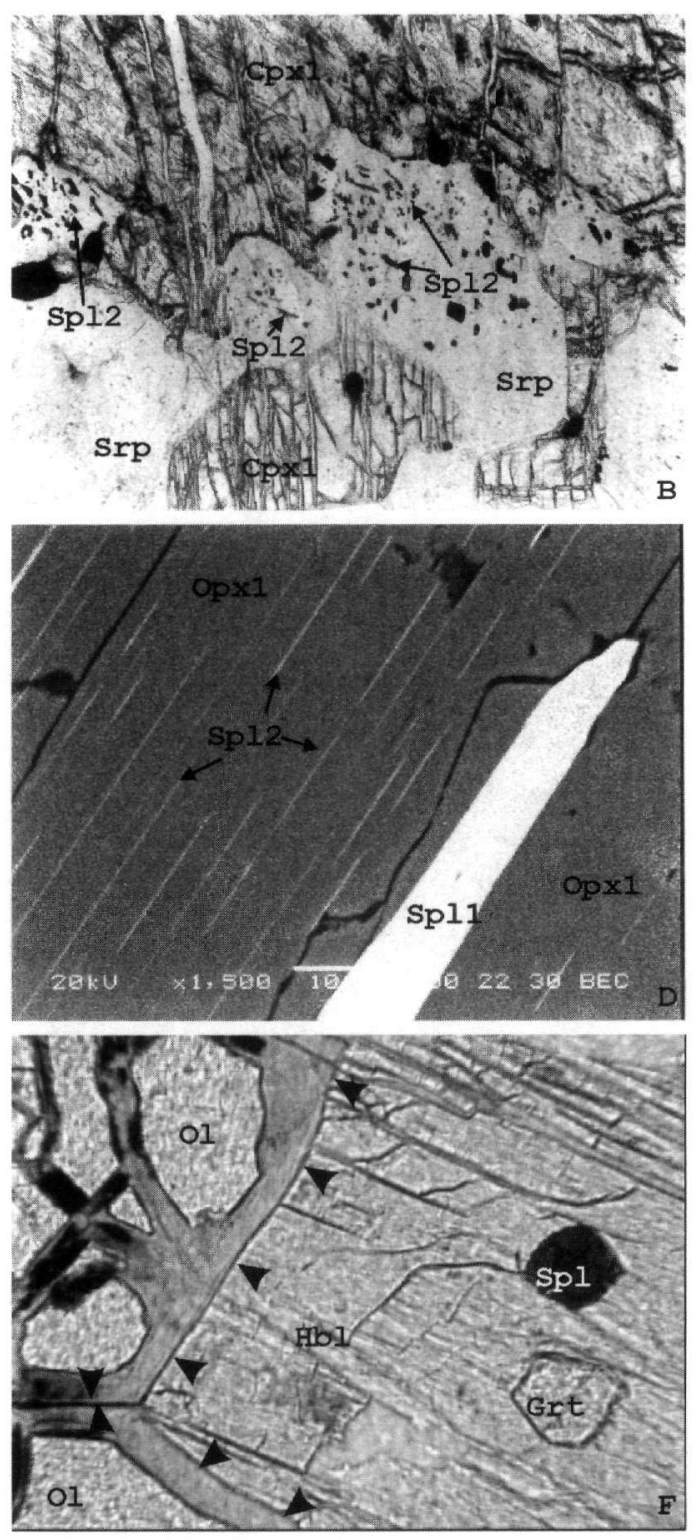

Plate 2: Garnet spinel peridotite:

A: Photomicrograph of spinel (Spl 1) showing compositional zoning (see text). Spll contains inclusions of spinel (Spl 2) and orthopyroxene symplectites interpreted as decomposition products of former garnet inclusions. Spl 1 is overgrown by later formed hornblende. Field of view $0.9 \mathrm{~mm}$, polarizer only. B: Photomicrograph of serpentinized elongated grains containing vermicular inclusions of spinel (Spl 2), are interpreted as decomposition products of former garnets. Garnet was associated with a HT clinopyroxene ( $\mathrm{Cpx}$ 1) containing exsolutions of Spl and Opx. Field of view $1.5 \mathrm{~mm}$, polarizer only. C: SEM image of clinopyroxene (Cpx 1) containing exsolution lamellae of Spl and Opx. D: SEM image of orthopyroxene (Opx 1) containing two generations of spinel exsolutions. Note the thick lamella is richer in chromium than the small ones (see text). $\mathbf{E}$ : SEM image of exsolution free recrystallized orthopyroxene (Opx 2) containing a garnet inclusion. F: Photomicrograph of hornblende with inclusions of garnet and spinel, being in contact to olivine that has been marginally serpentinized. Straight olivine hornblende phase boundaries suggest coexistence of the two phases. Field of view $0.9 \mathrm{~mm}$, polarizer only. 
peratures. Small light brown spinels (Spinel 2) homogeneous in composition showing $\mathrm{Cr} /(\mathrm{Cr}+\mathrm{Al})$ ratios $\sim 0.12$ 0.15 and $\mathrm{Mg} /(\mathrm{Mg}+\mathrm{Fe})$ ratios $\ni 0.72-0.76$, indicate like the rims from the zoned spinels, formation of spinel during cooling. Spinel 1 contains symplectites of spinel, ortho- and clinopyroxene replacing pseudomorphically an aluminous phase (Plate 2A), probably garnet. Symplectitic clino - and orthopyroxene are replaced in latter stages by hornblende and serpentine respectively. As is shown in Plate 2A the symplectite (garnet pseudomorph) inclusion shows corroded edges, suggesting that spinel 1 , is formed replacing the previous garnet, probably during decompression at still high pressures and temperatures. Serpentinized rounded or elongated grains containing minute vermicular spinels, $[\mathrm{Cr} /(\mathrm{Cr}+\mathrm{Al})=0.14-0.15]$ as those showing in the Plate $2 \mathrm{~B}$, are interpreted to represent previous garnets. Ortho- and clinopyroxene show $\mathrm{Al}_{2} \mathrm{O}_{3}$ contents ranging between 1.61-2.63 wt $\%$ and 0.9-2.10 wt\%, respectively. Large clino- and orthopyroxene crystals (Cpx 1, Opx1) contain exsolution lamellae of ortho- and clinopyroxene respectively as well as spinel exsolutions (Plate 2C,D) consistent with decreasing diopside and $\mathrm{Mg}$-Tschermak component of the original orthopyroxene and enstatite and Ca-Tschermak component of the original clinopyroxene through cooling. Two generations of spinel exsolusions are observed in orthopyroxene (Plate 2D). From older, wider spinel lamellae to younger, thiner spinel lamellae the $\mathrm{Cr} /(\mathrm{Cr}+\mathrm{Al})$ ration decreases from $0.17-0.18$ to 0.12 and the $\mathrm{Mg} /(\mathrm{Mg}+\mathrm{Fe})$ ratio increases from 0.71 to 0.75 , indicating that, in orthopyroxene, the solubility of $\mathrm{MgCrAlSiO}_{6}$ component decreases faster than the solubility of the $\mathrm{MgAl}_{2} \mathrm{SiO}_{6}$ component, with decreasing temperature. The compositions of the spinel exsolutions in pyroxene grains and of the interstitial spinel between exsolution-free pyroxene grains correspond to those of spinel $2(\mathrm{Cr} / \mathrm{Cr}+\mathrm{Al}$ ratios $\sim 0.13-0.15$ ). Exsolved diopside in orthopyroxene is mostly replaced by later formed hornblende. Integration of the exsolved spinel in orthopyroxene and that of exsolved spinel and orthopyroxene in clinopyroxene yields an original MgAl-Ts $+\mathrm{MgCr}-\mathrm{Ts}$ component of $10 \%$ in orthopyroxene and $\mathrm{CaAl}-\mathrm{Ts}+\mathrm{CaCr}-\mathrm{Ts}$ component of $\sim 10 \%$ ( $\sim 8 \% \mathrm{CaAl}-\mathrm{Ts}$ and $\sim 2 \% \mathrm{CaCr}-\mathrm{Ts})$ and enstatite component of $\sim 14 \%$, in Clinopyroxene, respectively.

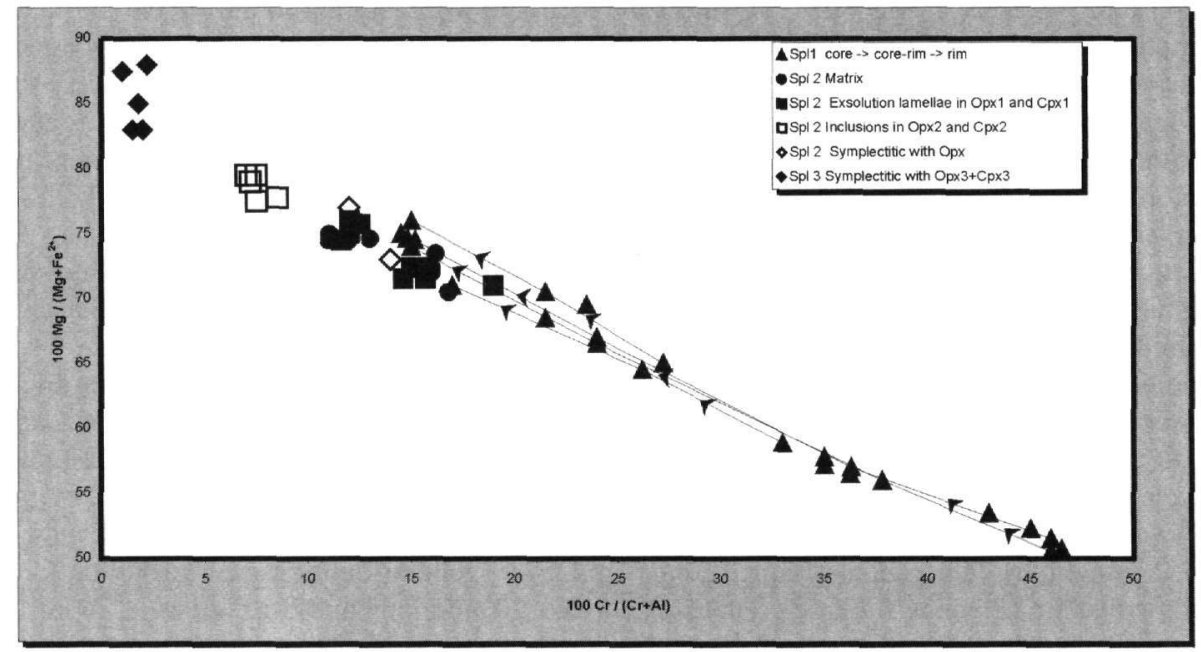

Figure 2: Chemical compositions of spinels from garnet-spinel peridotite in relation to $100 \mathrm{Cr} /(\mathrm{Cr}+\mathrm{Al}): 100 \mathrm{Mg} /$ $\left(\mathrm{Mg}+\mathrm{Fe}^{+2}\right)$.

Thus, an old (relict) mineral assemblage Ol1 $\left(\mathrm{Fo}_{0.9}\right)$ - Opx1-Cpx1-Spl1 $\left(\mathrm{X}_{\mathrm{cr}}^{\mathrm{spl}}=0.46\right)$-(Grt) indicates pressures of ca. $3 \mathrm{GPa}$, constrained by the continuous reaction $\mathrm{Grt}+\mathrm{Ol}\left(\mathrm{Fo}_{0.9}\right) \rightarrow \mathrm{Opx}+\mathrm{Cpx}+\mathrm{Spl}\left(\mathrm{X}_{\mathrm{cr}}^{\mathrm{spl}}=0.46\right)$ for an assumed temperature of $1200^{\circ} \mathrm{C}\left(\mathrm{O}^{\prime}\right.$ Neill, 1981). Assuming that $\mathrm{Cpx} 1$ was in equilibrium with the preexisting garnet, as textural relations in Plate 2B suggest, and by applying the $\mathrm{Cr}$-in-Cpx barometer and enstatite-in-Cpx thermometer (Nimis and Taylor 2000), on the recalculated Cpx1 composition, a temperature of $1235^{\circ} \mathrm{C}$ and a pressure of $2.6 \mathrm{GPa}$ are obtained. The Spl-Opx-Cpx symplectites replacing pseudomorphically a garnet inclusion in spinel 1 (Plate 2A), suggest a previous garnet peridotite stage at pressures $>3 \mathrm{GPa}$. Because of the absence of garnet exsolutions in Opx1 and Cpx1, preserved increments of decompression and cooling occurred within the stability field of spinel peridotite up to $\sim 1.8 \mathrm{GPa}$ for an assumed temperature of $\sim 900^{\circ} \mathrm{C}$, since exsolved and interstitial spinel has a $\mathrm{Cr} /(\mathrm{Cr}+\mathrm{Al})$ ratio $\sim 0.10$ (O'Neil, 1981). Sporadically exsolution-free recrystallized ortho- and clinopyroxene (Opx 2, Cpx2) coexisting with olivine, include an Al-rich spinel $\left(\mathrm{X}_{\mathrm{cr}}^{\mathrm{spl}}=0.08-0.1\right)$ that 
coexists with garnet $\left(\mathrm{Grs}_{14} \mathrm{Alm}_{21.5} \operatorname{Prp}_{60} \mathrm{Sps}_{2} \mathrm{Uvr}_{25}\right)$. Garnet and $\mathrm{Al}$-rich spinel grains are also observed as inclusions in hornblende and olivine formed in a later stage of exhumation (Plate 2F). The five phases Opx-Cpx-Spl $\left(\mathrm{X}_{\mathrm{cr}}^{\mathrm{spl}}=0.1\right)-\mathrm{Ol}\left(\mathrm{Fo}_{0.9}\right)$ - $\mathrm{Grt}$; constrain pressures $\sim 1.6 \mathrm{GPa}$ assuming temperatures of $800^{\circ} \mathrm{C}$ (cf. O'Neill, 1981); thus cooling occurred at still high pressures. Pressures of 1.4-1.6 GPa for a temperature of $800^{\circ} \mathrm{C}$ are also obtained applying the Al-in-Opx barometer of Brey and Köhler (1990) using the compositions of the exsolution free recrystallized orthopyroxene and that of garnet enclosed in the orthopyroxene (i.e. Plate $2 \mathrm{E}$ ).

During decompression and cooling, enstatite-diopside-spinel symplectites formed between adjacent garnet (of the garnet-pyroxenite or pyroxene garnetite layers) and olivine grains of the peridotite layer, (Plate 3F) according to the reaction $\mathrm{Grt}+\mathrm{Ol} \rightarrow \mathrm{Opx}+\mathrm{Cpx}+\mathrm{Spl}(\mathrm{Spl} 3)$. Spinel 3 shows a high $\mathrm{Mg} /(\mathrm{Mg}+\mathrm{Fe})$ ratio of $(0.82-$ 0.88 ) and a low $\mathrm{Cr}_{2} \mathrm{O}_{3}$ content $\left(\mathrm{X}_{\mathrm{cr}}^{\text {spl }}=0.012\right.$ ) (see Fig. 2), constraining the above reaction at pressures $<1.4$ $\mathrm{GPa}$ (cf. O'Neill, 1981).

At this stage, access of water triggered a variety of hydration reactions. Garnet, clinopyroxene and spinel inclusions in hornblende ( $\mathrm{Si}=6.5-6.8$ atoms p.f.u.) (Plate $2 \mathrm{~F}$ ) and olivine suggest that the reactions $\mathrm{Grt}+\mathrm{Cpx}+\mathrm{W} \rightarrow \mathrm{Ol}+\mathrm{Hbl}$ and $\mathrm{Opx}+\mathrm{Cpx}+\mathrm{Spl}+\mathrm{W} \rightarrow \mathrm{Ol}+\mathrm{Hbl}$ took place. It is noted that hornblende with Si content 6.5-6.8 atoms p.f.u, and associated with spinel in ultramafic rocks indicates upper amphibolite/granulite facies conditions (Evans, 1982). At lower P-T conditions hornblende + spinel are replaced by tremolite + chlorite. At still lower temperatures olivine is replaced by antigorite.

\subsection{Spinel-garnet clinopyroxenite, clinopyroxene garnetite and olivine clinopyroxenite}

The clinopyroxenites occur as millimetre to several centimetres thin layers within the peridotite (Plate 3A) as a result of strong flattening and shearing during HP/HT-metamorphism; locally the thickness of pyroxenites exceeds one meter. They generally show high $\mathrm{MgO}$ and low $\mathrm{SiO}_{2}$ contents $\left(\mathrm{SiO}_{2}\right.$ ranges between $39-42 \%, \mathrm{Al}_{2} \mathrm{O}_{3}$ 12.5-14.5\%, $\mathrm{FeO}_{\text {tot. }} 8.2-9.5 \%, \mathrm{MgO} 23-27 \%$ and $\mathrm{CaO} 12.5-14.5 \%$ ), resulting in an olivine and anorthite-rich norm composition with additional diopside and $\mathrm{Ca}_{2} \mathrm{SiO}_{4}$. Some layers may contain up to 80 volume \% garnet, thus characterised as clinopyroxene garnetites. They are interpreted as mantle cumulates that crystallized from melts at high pressures, and subsequently deformed and recrystallized at still high temperatures and pressures.

The spinel-garnet clinopyroxenites show the mineral assemblage $\mathrm{Cpx}+\mathrm{Grt}+\mathrm{Spl}+\mathrm{Hbl} \pm \mathrm{Ol}$, the clinopyroxene garnetites $\mathrm{Grt}+\mathrm{Cpx} \pm \mathrm{Hbl}$ and the olivine clinopyroxenites $\mathrm{Cpx}+\mathrm{Ol}$. A Mg-rich ilmenite $(\mathrm{MgO} 8-8.5 \%)$ is present in all pyroxenites.

Garnet, spinel and olivine inclusions in cumulate clinopyroxene crystals suggest fractional crystallization of cumulate minerals garnet, olivine and clinopyroxene from the melt and crystallization of the original clinopyroxene in the stability field of garnet pyroxenite (Plate 3C,E).

In spinel-garnet clinopyroxenite, clinopyroxene and garnet coexist with spinel and olivine. Larger clinopyroxene grains display a compositional zoning with $\mathrm{Al}_{2} \mathrm{O}_{3}$ content decreasing from ca. $4.5 \mathrm{wt} \% \mathrm{Al}_{2} \mathrm{O}_{3}$ in the core to ca. 2.5 3.2 wt \% $\mathrm{Al}_{2} \mathrm{O}_{3}$ at the rim. If olivine is present, the core and rim $\mathrm{Al}_{2} \mathrm{O}_{3}$ contents of such clinopyroxenes are ca. 3.58 and $1.7 \mathrm{wt} \%$, respectively. However, abundant exsolution lamellae of garnet (up to $\sim 8$ vol.\%) and, to a lesser extent, spinel in the core of the larger Cpx grains (Plate 3B,C,D) indicate a much higher $\mathrm{Al}_{2} \mathrm{O}_{3}$ content for the original clinopyroxene ( $\left.\mathrm{Cpx} 1\right)$. Two generations of garnet exsolution formed during cooling of pyroxenite (Plate 3C). Large garnet rods, up to $\sim 300 \mu \mathrm{m}$ long and 6-10 $\mu \mathrm{m}$ wide, represent the first generation and very thin garnet rods, $\sim 30-60 \mu \mathrm{m}$ long and $\sim 2 \mu \mathrm{m}$ wide, associated with exsolutions of spinel (Plate 3D) represent the second generation. The rims of clinopyroxene crystals are exsolution free and are in textural equilibrium with the matrix garnet and spinel grains and, also with olivine, if present. They have a similar composition with the homogeneous matrix clinopyroxenes ( $\mathrm{Cpx} 2)$, which have no garnet exsolutions. Applying clinopyroxene thermobarometry (Gasparik, 1984) in the olivine-bearing garnet clinopyroxenite, the core composition of a clinopyroxene having $7.6 \% \mathrm{Ca}-\mathrm{Ts}$ component $\left(\mathrm{Al}_{2} \mathrm{O}_{3} 3.58 \%\right)$ and $14 \%$ enstatite component (Cpx1) yield minimum P-T condition of $1160^{\circ} \mathrm{C}$ and $2.4 \mathrm{GPa}$ since orthopyroxene is not present to saturate the enstatite component in the clinopyroxene. Integration of the exsolved garnet ( $\sim 5 \% \mathrm{Grt})$ into the clinopyroxene suggests higher temperatures $\left(\sim 1240^{\circ} \mathrm{C}\right)$ for clinopyroxene crystallization.

The composition of garnet depends on the bulk rock composition of the pyroxenites. In the olivine-free layers the composition of garnet is: $\mathrm{Grs}_{22-29}, \operatorname{Prp}_{43-49}, \mathrm{Alm}_{24-31}, \mathrm{Sps}_{0.5-1.2}$ and in the olivine bearing ones: Grs ${ }_{17-25} \operatorname{Prp}_{52-}$ ${ }_{55} \mathrm{Alm}_{23-27} \mathrm{Sps}_{01}$. Rare older Grt 1 shows compositional zoning with core composition ( $\mathrm{Grs}_{25} \operatorname{Prp}_{51.5} \mathrm{Alm}_{22.5} \mathrm{Sps}_{0.7} \mathrm{Uv}_{0.7}$ ) and rim composition $\left(\mathrm{Grs}_{18.5} \operatorname{Prp}_{54} \mathrm{Alm}_{26} \mathrm{Sps}_{1} \mathrm{Uv}_{0.3}\right)$. The lower grossular and uvarovite components, the higher pyrope and almandine components, and the lower $\mathrm{Mg} /(\mathrm{Mg}+\mathrm{Fe})$ ratio of the rim in comparison to the core 

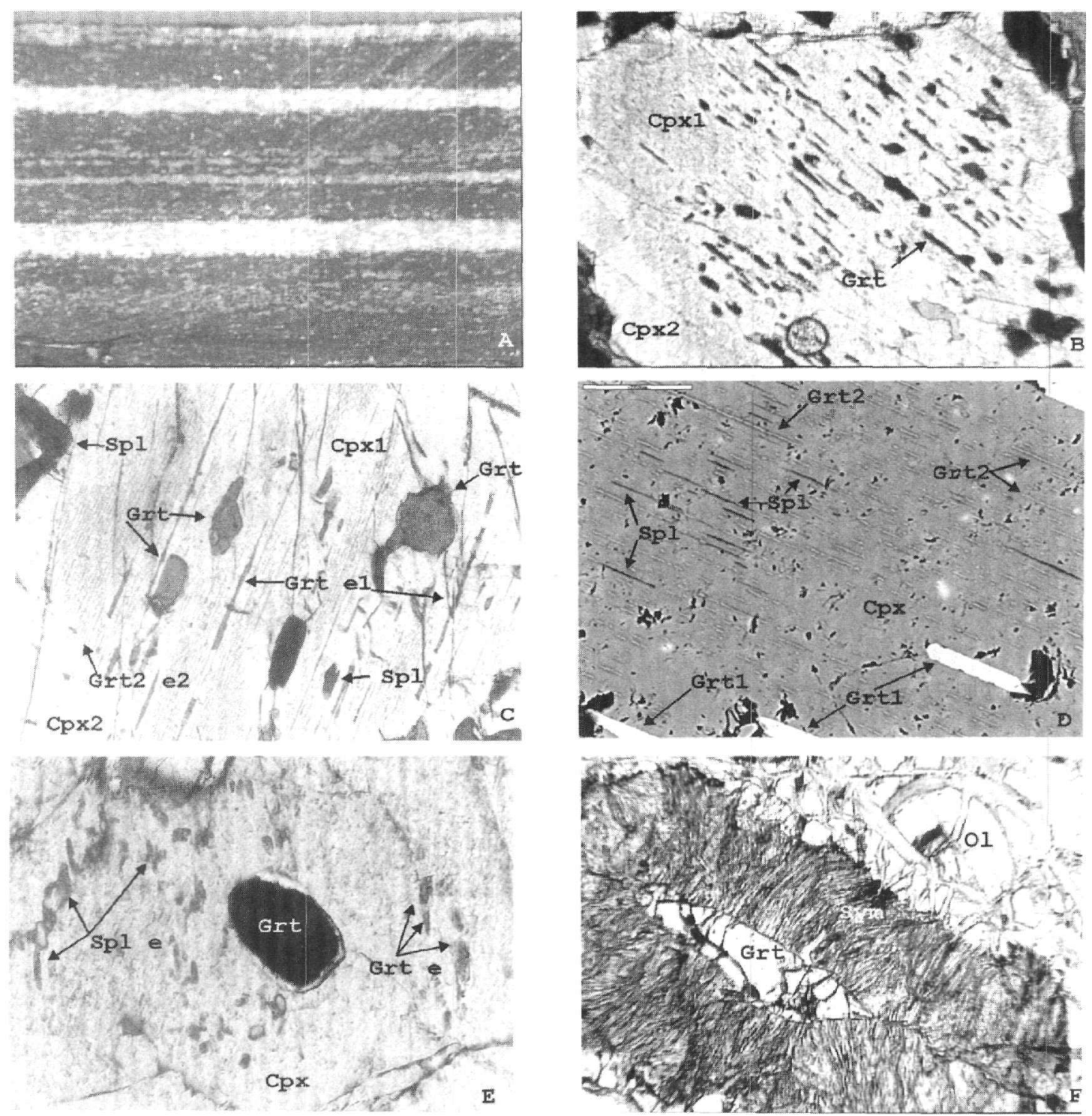

Plate 3: Spinel-garnet clinopyroxenite:

A: Jayorirg of alternazing garnet-spinel pericotite diark and garnez pycoxerize

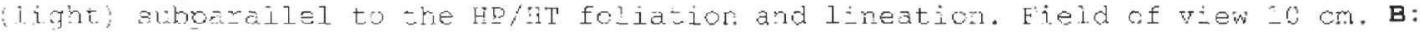
Photor crograpi of clinopyroxene (Cox i) showing exsolution zameliae of garmet ju

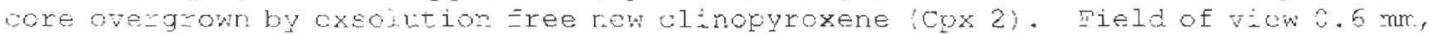
crossed volirs. C: Protonicrograoh of cinopyromene (Cpxi) witr incilsiors of garne: (Grt, rounded arci in pant elongated, corroded grains) ard spinel (Spl; and exso-uticn lazciae of ganet. Two generaticns of garnet exsc-utions occur; wide amelae :Gut ol and very thir (Crt ez). Notc tre exsolution free nen

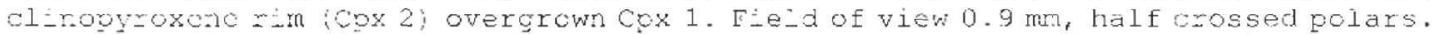
D: SEM image of cinopyroxore (Cpxi) containin exsolution lame lae of gannet and spine.- Two gererafiors of garrez exsolutions occur; wido hameliae (Grt-i and very thin (Grt2). E: Zhotomicrograpi of clinopyroxene (Cpxl) contaring garret inclusior (Gro: Exso-ltions of spinel (Spl-e) and garnet (Grt-c), are, also, observed. Ficlci

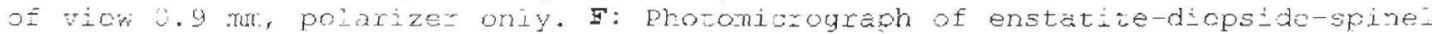
Spl 3) symplectites (Sym) formed as reaction procicts between garnet from syroxer fe layor and adjacent olivine from peridotile idyer. Fiejd of view 1.5 mm, volarizen onjy. 
composition suggest that garnet formed during decompression and cooling (Jenkins and Newton, 1979).

Garnet exsolved from Cpx 1 has a similar composition to the matrix one $\left(\operatorname{Grs}_{25} \operatorname{Prp}_{46} \mathrm{Alm}_{28} \mathrm{Sps}_{1}\right.$ : in olivine bearing pyroxenites $\mathrm{Grs}_{18} \operatorname{Prp}_{54} \mathrm{Alm}_{27} \mathrm{Sps}_{01}$ ). Since garnet exsolutions are formed during a post deformational static annealing stage, as the textural relations indicate, matrix garnet, exsolution-free clinopyroxene rims and exsolution-free matrix clinopyroxene have recrystallized and equilibrated at that stage. Garnet-clinopyroxene geothermometry (Ellis \& Green, 1979) between exsolved garnet-clinopyroxene host and matrix garnet-exsolutionfree matrix clinopyroxene pairs yielded equilibration temperatures ranging between $750-790^{\circ} \mathrm{C}$ for assumed pressure of $1.5 \mathrm{GPa}$. Higher values $\left(823^{\circ} \mathrm{C}\right)$ are obtained from Grt 1 core - Cpx 1 core composition.

\subsection{Eclogites}

Throughout the Kimi Complex boudins of amphibolitized eclogites ranging in size from a few dm to some tens of meters occur. According to their mineral assemblages they are characterized as common eclogites, and kyanite eclogites.

\subsubsection{Common eclogites}

MPQ aggregates pseudomorphic after coesite included in garnet (Plate 1A) are interpreted as UHP indicators in the common eclogites. The high-P mineral assemblage is Grt-Cpx-Qtz-Rt. Elongated garnet-clinopyroxene aggregates show a HP/HT deformation (Plate 4A). Large clinopyroxene grains (Cpx 1) show a compositional zoning with jadeite component decreasing from the core $\left(\mathrm{jd}_{25}\right)$ to the rim $\left(\mathrm{jd}_{20-15}\right)$, indicating an equilibration tendency of the clinopyroxene to pressure decrease. With decreasing temperature and pressure symplectites of clinopyroxene (Cpx2)-plagioclase and hornblende-plagioclase replace $\mathrm{Cpx} 1$. Cpx $2\left(\mathrm{jd}_{15-10}\right)$, which is in equilibrium with symplectitic plagioclase $\left(\mathrm{An}_{27.32}\right)$ constrains an equilibration stage at $\sim 1.2 \mathrm{GPa}$ for assumed temperature of $700^{\circ} \mathrm{C}$. During continuing cooling and hydration, poikiloblastic brown-green hornblende, reaching several centimeters in size, grew at the expense of garnet and clinopyroxene. This hornblende contains numerous inclusions of garnet, clinopyroxene, (with corroded edges), quartz and rutile (Plate 4B). Garnet-hornblende geothermometry (Graham and Powell, 1984) using rim compositions of garnet inclusions in hornblende yielded $670 \pm 40^{\circ} \mathrm{C}$.

\subsubsection{The Smigada eclogite}

$4 \mathrm{Km}$ to the $\mathrm{W}$ of Smigada village on the road to Kimi village, a boudin of amphibolitized garnet-rich eclogite with an exposure of $\sim 10 \mathrm{X} 20 \mathrm{~m}$ occurs within intensely mylonitized and retrogressed gneisses. Garnet-rich and Clinopyroxene-rich layers are isoclinally folded imprinting a (U)HP deformation. Quartz-Scapolite rich pockets, veinlets or garnet-scapolite-hornblende layers with interstitially growing equigranular strain-free scapolite and hornblende grains record a post-eclogitic static annealing reequilibration stage, indicated by the presence of a sulfate rich fluid phase. A muscovite pegmatite intrudes the eclogite cutting across the eclogite foliation.

The total mineral assemblage of the amphibolitized Smigada eclogite is Grt-Cpx-Scp-Hbl-Qtz-Czo-Ky-KfsAb-Pl-Rt-Ttn-Py.

Several garnet and clinopyroxene generations are present: Older garnet (1) showing larger grain size (400$600 \mu \mathrm{m}$ ) is characterized by a homogeneous composition except at the outermost rim. The core composition is $\mathrm{Grs}_{24}, \mathrm{Alm}_{47}, \operatorname{Prp}_{29}$, at the rim $\mathrm{MgO}$ slightly decreases and $\mathrm{CaO}$ increases. The composition of the younger equidimensional and euhedral garnets $(\sim 200-300 \mu \mathrm{m})$ is similar to the rims of the older garnets $\left(\mathrm{Grs}_{28}, \mathrm{Alm}_{45}\right.$, $\operatorname{Prp}_{25}, \mathrm{Sps}_{0.1}$. Garnet 1 contains inclusions of $\mathrm{K}$-feldspar, quartz, rutile kyanite and composite grains consisting of $\mathrm{Kfs}-\mathrm{Ab}-\mathrm{Qtz}$ and $\mathrm{Hbl}+\mathrm{Cpx}$. Subradial cracks emanate from the $\mathrm{K}$-feldspar inclusions into the garnet host (Plate 1C) indicating that they have formed by volume increase of the inclusions during phase transformation of a denser phase to less dense one (i.e. K-cymrite $\rightarrow \mathrm{K}$-feldspar $+\mathrm{W}$ ). Garnet 2 is commonly free of inclusions.

Large clinopyroxene (Cpx 1) single grains ( $\geq 300 \mu \mathrm{m}$ in length) and smaller (Cpx 2) grain aggregates (single grain size $\sim 100 \mu \mathrm{m}$ ) occur. Cpx 1 shows a compositional zoning with jadeite component slightly decreasing from the core $\left(\mathrm{jd}_{20-25}\right)$ to the rim $\left(\mathrm{jd}_{20-15}\right)$ that corresponds to the jadeite component of Cpx 2. Cpx 1 contains inclusions of composite grains consisting of $\mathrm{Hbl}+\mathrm{Kfs}, \mathrm{Hbl}+\mathrm{Qtz}+\mathrm{Kfs}$, $\mathrm{Kfs}+\mathrm{Ab}$ as well as exsolution lamellae of quartz (Plate IB). Exsolution lamellae of quartz in clinopyroxene have been identified only in clinopyroxenes from eclogites and garnet clinopyroxenites of several UHP terranes and are interpreted as exsolution products of a precursor, supersilicic clinopyroxene stabilized at UHP conditions (Liou et al. 1998). Local reaction rims of new, euhedral garnet (Grt 2, Plate 4C) around Cpx 1 indicate garnet formation at the expense of Cpx 1. Cpx 2 forms equigranular grains and is free of inclusions. 
Applying the garnet-clinopyroxene Fe-Mg exchange geothermometer of Ellis and Green (1979) to Grt 1 core and Cpx 1 core compositions, temperatures in the range of $900-950^{\circ} \mathrm{C}$ are obtained for minimum pressure of $4 \mathrm{GPa}$, if we assume that the eclogite shared a common UHP metamorphism with the diamond-bearing neighboring metapelites at the peak pressure. Grt 2 and Cpx 2 compositions yielded $730-790^{\circ} \mathrm{C}$ for an assumed pressure of $1.5 \mathrm{GPa}$.

Influx of water and oxidized conditions triggered the formation of kelyphitic and diablastic hornblende and scapolite replacing garnet and clinopyroxene (Plate 4D). Scapolite formed aggregates of equidimensional strain free grains showing low energy grain boundary configuration $\left(120^{\circ} \mathrm{C}\right.$ triple junctions). In some leucocratic pockets of the rock, scapolite coexist with plagioclase. Scapolite is Ca-rich with 70-80\% meionite component and 20 $30 \%$ marialite component, whereas the coexisting plagioclase is Na-rich having an anorthite component in the range 30-35\%. Garnet-hornblende geothermometry (Graham and Powell 1984), using rim composition of garnet inclusions in hornblende, yieded $650 \pm 30^{\circ} \mathrm{C}$ for this stage.

\subsubsection{Kyanite eclogite}

$1 \mathrm{Km}$ to the east of Kimi village (Fig. 1), in close association with major ultramafic boudins, a small boudin of a partially amphibolitized kyanite eclogite occurs showing the mineral assemblage Grt-Cpx-Pl-Hbl-Kfs-RtKy-Scp- Czo. Quartz is very rare and is present only as inclusions in garnet associated with kyanite. Characteristic are elongated, sigmoidal shaped mineral domains (length to height ratio of about 10:1) mainly consisting either of Na-poor clinopyroxene $\left(\mathrm{Jd}_{10-15}\right)$-hornblende-plagioclase-garnet or garnet-plagioclase ( \pm hornblende) (Plate 4E). These are interpreted as pseudomorphs after plastically deformed garnet grains.

Relict mineral assemblages linked to this early stage are rarely preserved. Within these domains relics of older garnet $1\left(\mathrm{Grs}_{17} \operatorname{Alm}_{36} \operatorname{Prp}_{46} \mathrm{Sps}_{01}\right)$ includes tiny kyanite $(1-5 \mathrm{~mm})$ and quartz grains (Plate $\left.4 \mathrm{~F}\right)$. Thus, an older mineral assemblage is Grt-Ky-Qtz indicating P-T conditions of a prograde stage above the stability field of plagioclase.

Younger idiomorphic garnet (Grt 2) grains $\left(\mathrm{Grs}_{22} \operatorname{Alm}_{41.5} \operatorname{Prp}_{35} \mathrm{Sps}_{01.5}\right.$; grain diameter c. $\left.200 \mu \mathrm{m}\right)$ include larger kyanite crystals similar in size to the matrix kyanites (up to $100 \mu \mathrm{m}$ ), $\mathrm{K}$-feldspar and rutile. Thus, a younger mineral assemblage is Grt 2-Cpx-Ky-Kfs-Rt-Scp possibly formed above the stability field of muscovite and quartz. Kelyphitic hornblende coronas surround clinopyroxene and garnet grains indicating hydration. At this stage plagioclase $\left(\mathrm{An}_{32-35}\right)$ is intergrown with clinopyroxene and hornblende. Since quartz and corundum are absent from the rock matrix, the formation of plagioclase replacing eclogitic garnet and clinopyroxene is restricted between the pressure dependent reactions $\mathrm{Pl} \rightarrow \mathrm{Cpx}+\mathrm{Qtz}$ and $\mathrm{Cpx}+\mathrm{Ky} \rightarrow \mathrm{Pl}+\mathrm{Co}$. The intersection of the above reaction curves calculated for analysed plagioclase and clinopyroxene compositions with the garnet (Grt 2)clinopyroxene Fe-Mg equilibrium constrains the P-T conditions for the amphibolitization stage of the kyanite eclogite between 1.1 and $1.2 \mathrm{GPa}$ and $700-750^{\circ} \mathrm{C}$. During continued annealing, phengitic muscovite $(\mathrm{Si}=6.6$ p.f.u) replaced K-feldspar and kyanite, and clinozoisite replaced garnet, kyanite and plagioclase suggesting further hydration.

\subsection{Granodiorite gneisses}

Large boudins of granodiorite gneisses containing numerous mafic enclaves also preserve fabrics of a high$\mathrm{P} /$ high-T deformation. Elongated mafic enclaves define a distinct mesoscopic foliation and lineation (Plate 5A). The mineral assemblage of the granodiorite gneiss is $\mathrm{Grt}-\mathrm{Hbl}-\mathrm{Pl}\left(\mathrm{An}_{30}\right)-\mathrm{Qtz}-\mathrm{Czo}-\mathrm{Ms} \pm \mathrm{Bt}$.

Deformation of the granodiorite gneisses at high pressures is constrained by the intrusion depths of trondhjemitic pegmatites crosscutting the foliation plane (Plate $5 \mathrm{~A}$ ). The mineral assemblage of the pegmatite is $\mathrm{Ms} \pm \mathrm{Pg}-\mathrm{Pl}-\mathrm{Czo}-\mathrm{Qtz} \pm \mathrm{Ky} \pm \mathrm{Grt}$. Clinozoisite and scarce kyanite are armoured inclusions in plagioclase $\left(\mathrm{An}_{30}\right)$ (Plate 5B). They are interpreted to have formed by the reaction $\mathrm{Pl} \rightarrow \mathrm{Czo}+\mathrm{Ky}+\mathrm{L}$, above the wet melting of granite minimum i.e. $>1.1 \mathrm{GPa} / 670{ }^{\circ} \mathrm{C}$ (Johannes, 1985). This evidences pegmatite intrusion and thus deformation of gneisses, at pressures above $1.1 \mathrm{GPa}$. Plagioclase shows compositional zoning from $\mathrm{An}_{30}$ in the core to $\mathrm{An}_{15}$ at the rim. Local symplectitic intergrowths of plagioclase $\left(\mathrm{An}_{15}\right)$ with clinozoisite, muscovite and quartz (Plate $5 \mathrm{C}$ ) indicates that the pegmatite has been completely crystallized at $1.05 \mathrm{GPa}$ and $630^{\circ} \mathrm{C}$ (see Johannes, 1985). At the postdeformational static annealing stage hydration reactions produced in the granodiorite gneiss idiomorphic garnet and clinozoisite grains in plagiocalse and unoriented muscovite \pm paragonite flackes at the expense of plagioclase and K-feldspar. 

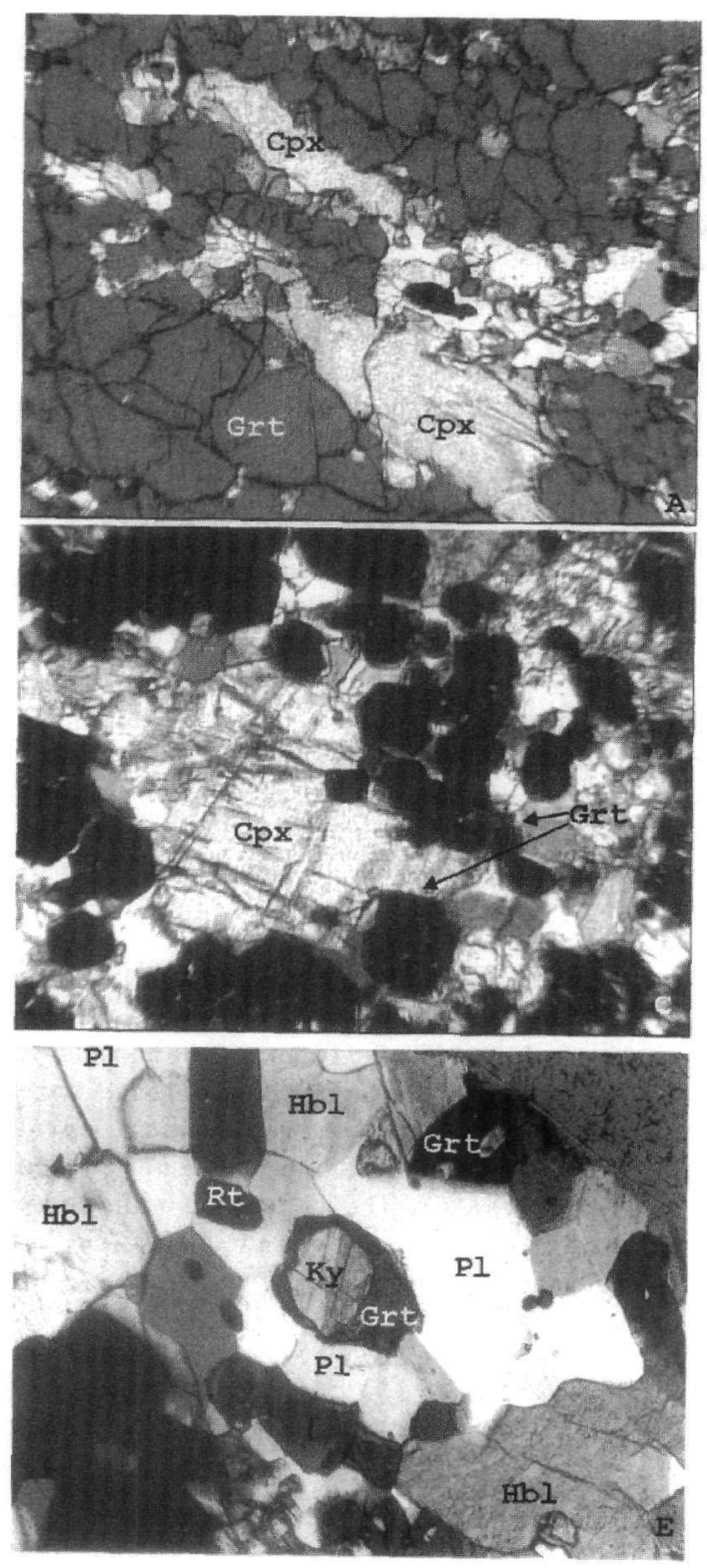
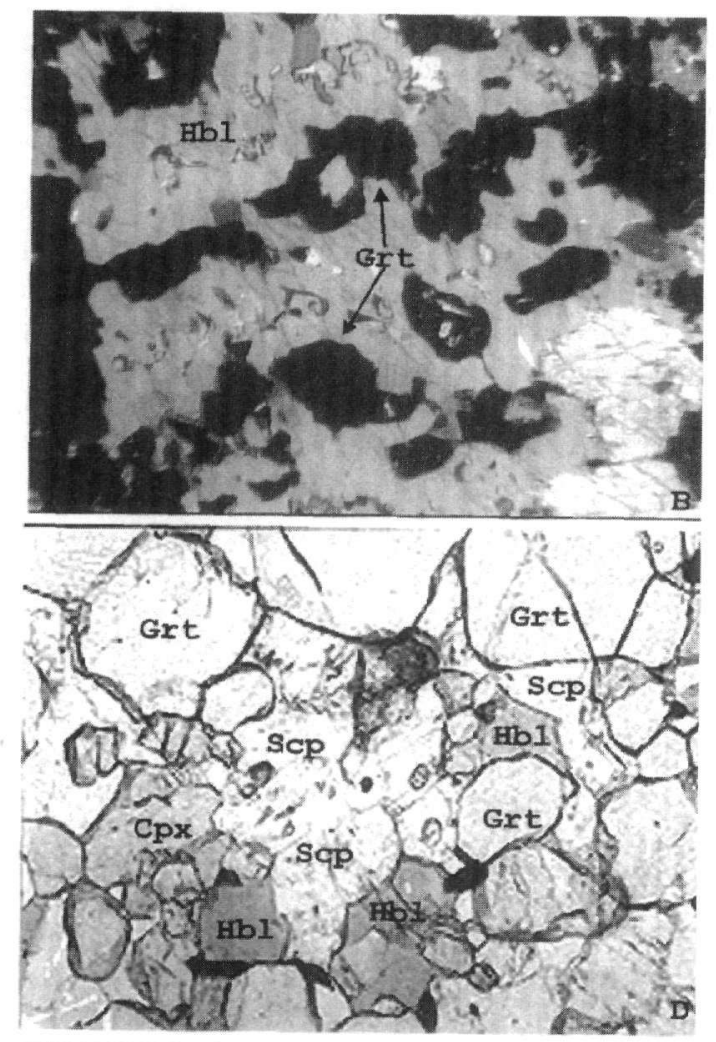

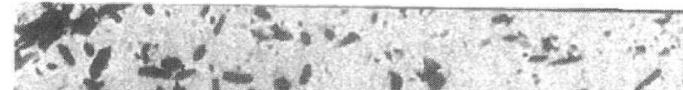

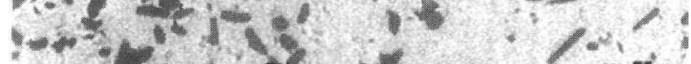

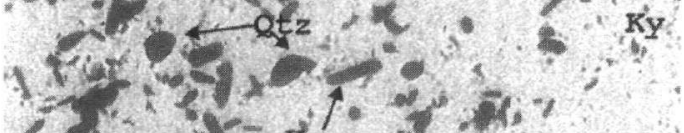

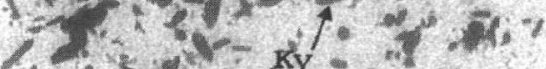

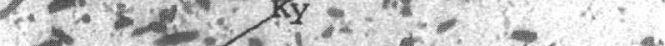

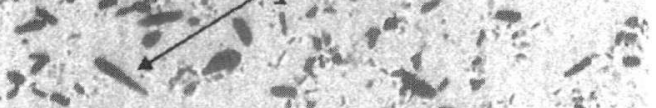

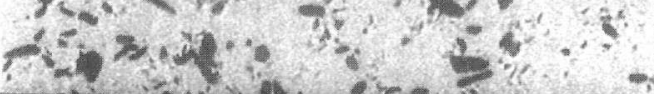

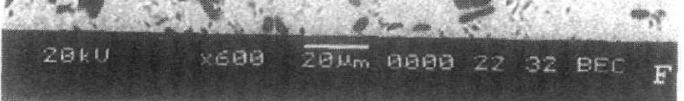

\section{Plate 4: Eclogites:}

A: Pactcricrograph of syndoformational association of garrec (Ert) and

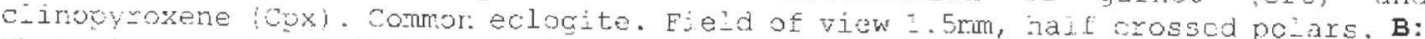
Photuicrograpr. of diablastic hornbiende (abl) overgrowing garret lavers (Grt) dirirg the postaefornatioral static anmealing/reeglilibration stage. common coichite. Fieid ôt view $2.2 \mathrm{~mm}$, crossed poiars. C: Pnotonicrograph of jaiomorprizo garnets (Cr. 2) overgrowing cinopyroxene (Cpxl) during the postcieformazioral scatio anrealirg/reequilibration stage. Smigacia eclogite. Fieid of view $1.5 \mathrm{~m}$, crossed polazs. D: Screoitto grains (Scp) associated with horrblende (Hbl) formod at the exporso of garnet ard clinopyroxene. Smigada eclogite. Eiclc of view J.5 mri, ralf-crossed polars. E: Procomicrograph of plagiocise (Pl)-hornbiende (Hol) agcregatos replacing deformed garnet porolyroblast. In the contre of thc ohcto, garate -ncilces large kyante grain Ky. Fielci of view 1.5 nu, crossea polars. F: SEM Mage showirg ninlte kyanite iKy) and quartz (Qtzj jnclusicns in eclogitic garnet. Kyanite eciogite. 

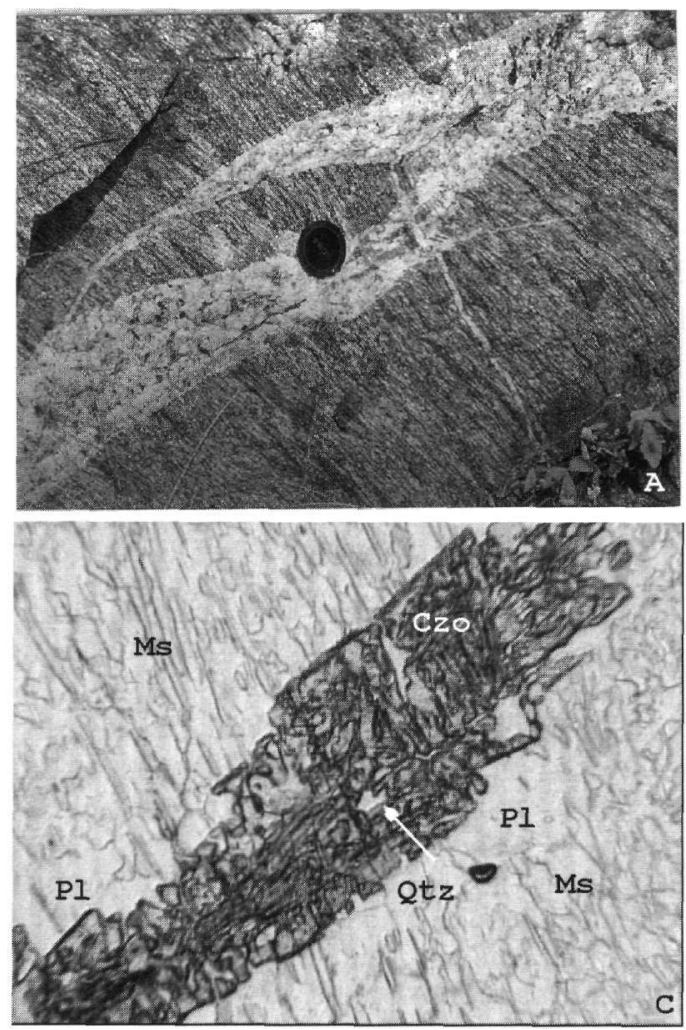
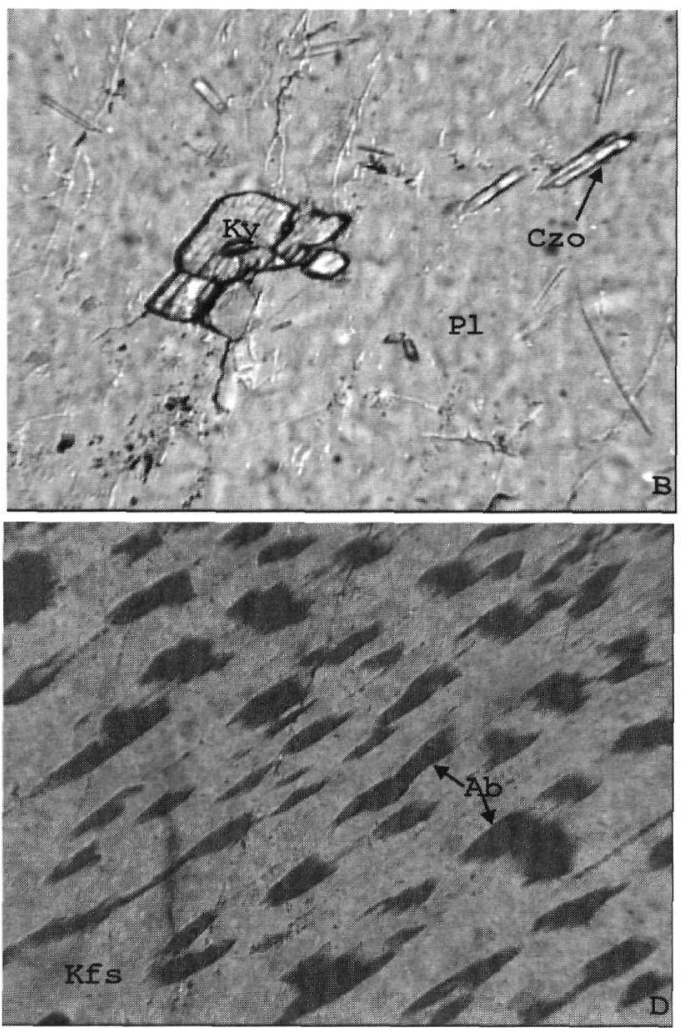

Plate 5: Granodiorite gneisses-Trondhjemitic dykes-migmatites

A: Elongated mafic enclaves in a granodiorite gneiss having long axis/short axis ratios of more than 20:1 define a HP/HT foliation/lineation. Trondhjemitic dyke intruded during the postdeformational static annealing/reequilibration stage cuts across the foliation. B: Photomicrograph of armored kyanite showing corroded rims included in plagioclase (An 30). Trondhjemitic dyke. Field of view $0.9 \mathrm{~mm}$, polarizer only. c: Photomicrograph of symplectitic intergrowth of oligoclase (An 15) with muscovite and quartz. Tronthjemitic dyke. Field of view $1.5 \mathrm{~mm}$, Polarizer only. D: Photomicrograph of K-feldspar showing perthitic exsolution in a migmatitic Grt-Bigneiss. Field of view $0.9 \mathrm{~mm}$, crossed polars.

\subsection{Quartz-feldspar gneisses and Pelitic gneisses}

Most of the volume of quartz-feldspar and pelitic gneisses was affected by partial melting and preserve migmatic structures. In these rocks UHP indicator minerals are not preserved; migmatization has destroyed almost completely previous mineral assemblages. Migmatite boudins contain either phengite or biotite. The mineral assemblage of phengite migmatites is Phen-Grt-Kfs-Pl-Qtz and that of the melanocratic interlayers $\mathrm{Bt}+\mathrm{Grt}+\mathrm{Kfs}+\mathrm{Pl}+\mathrm{Qtz}$, with perthitic and antiperthitic exsolutions in K-feldspar and plagioclase, respectively (Plate 5D). Some migmatite boudins consist of alternating $\mathrm{cm}$ thick melanocratic garnet-rich layers ( $>30 \mathrm{vol} \%$ ) and leucocratic quartz-feldspar-rich layers.

These migmatites have the mineral assemblage $\mathrm{Grt}+\mathrm{Pl}+\mathrm{Kfs}+\mathrm{Qtz}+\mathrm{Rt} \pm \mathrm{Bt}$, indicating that migmatization occurred at $\mathrm{P}-\mathrm{T}$ conditions above the dehydration melting reaction $\mathrm{Bt}+\mathrm{Ms}+\mathrm{Pl}+\mathrm{Qtz} \rightarrow \mathrm{Grt}+\mathrm{Kfs}+\mathrm{L}$ (i.e. $>800$ ${ }^{0} \mathrm{C}$ and $1.4 \mathrm{GPa}$, Le Breton \& Thompson, 1988). Garnet contains inclusions of quartz, rutile and rarely biotite. Subradial fractures emanate from quartz inclusions into the garnet host suggesting that they were former coesite. Matrix biotite replaces garnet indicating formation of biotite during cooling and hydration.

\subsection{High alumina metapelites}

Locally, kyanite-bearing migmatitic metapelites preserve UHP relics and mineral assemblages and textures allowing the unravelling of significant parts of the exhumation trajectory of the UHP Kimi complex. Garnet (Grt 
1) and kyanite (Ky 1) porphyroblasts contain minute carbon cubes and octahedra of partially or completely graphitized diamonds (Plate 1D). Sodic garnet porphyroblasts (Mposkos and Kostopoulos 2001) contain silica and apatite rods and rutile needles (Plate 1E,F) interpreted as exsolutions from a supersilicic garnet (Collerson et al. 2000). Diamond inclusions constrain minimum pressures at $3.9 \mathrm{GPa}$ for an assumed temperature of $900^{\circ} \mathrm{C}$ (Chatterjee et al. 1998) for the UHP stage, while the supersilicic garnet indicates pressures of $\sim 7 \mathrm{GPa}$ (Mposkos and Kostopoulos 2001).

A few sections of the exhumation path can be constrained based on the mineral compositions, mineral assemblages and textures formed in the high-alumina metapelites at any particular stages of exhumation (for mineral compositions, textures and mineral reactions in high-alumina metapelites see Mposkos and Liati, 1993).

Melt segregations formed pockets of leucosome consisting of aggregates of small unoriented muscovite and biotite flakes, kyanite rods and equidimensional strain free quartz and plagioclase grains, indicating crystallization of the melt at static conditions.

Garnet porphyroblasts (Grt 1) contain inclusions of kyanite $(\mathrm{Ky} 1)$, rutile, biotite $(\mathrm{Mg} /(\mathrm{Mg}+\mathrm{Fe})=\mathrm{Mg} \#$ $0.67)$ and quartz. They also include aggregates consisting of biotite + plagioclase + kyanite + quartz \pm muscovite. Kyanite forms small unoriented rods intergrown with biotite (Ky 2). These aggregates seem to be formed as decomposition products of a previous inclusion phase (probably phengite) reacted with the garnet host.

Garnet porphyroblasts and matrix muscovite are replaced by biotite $(\mathrm{Mg} \#=0.54-0.56)$ and kyanite $(\mathrm{Ky} 2)$ according to the pressure dependent continuous reaction $\mathrm{Grt}+\mathrm{Ms} \rightarrow \mathrm{Bt}+\mathrm{Ky}+\mathrm{Qtz}$ above the stability field of staurolite. This is associated with $\mathrm{Fe}, \mathrm{Ca}$ and $\mathrm{Mn}$ increase and $\mathrm{Mg}$ decrease at the garnet rim in contact with biotite (Fig.8 in Mposkos and Liati 1993). According to Le Breton and Thomson (1988) the above reaction occurs at $\sim 1.1 \mathrm{GPa}$ for assumed temperature of $700^{\circ} \mathrm{C}$. Grt-Pl-Ky-Qtz geobarometry (Koziol \& Newton, 1988) and garnet-biotite geothermometry (Ferry and Spear, 1978) yielded pressure of 0.9-1.1 GPa and temperature of $700 \pm 40^{\circ} \mathrm{C}$.

Further cooling crossed the stability field of Grt-Ky-Chl (Vuichard and Ballevre, 1988) verified by garnet (Grt 2) and chlorite (Mg\# 0.75) formation at the expense of kyanite (Ky 1) and biotite ( $\mathrm{Mg \#} \mathrm{0.73).}$

A remarkable change in the exhumation and cooling path is imprinted by staurolite formation replacing kyanite and garnet according to the water consuming reactions Grt $+\mathrm{Ky}+\mathrm{W} \rightarrow \mathrm{St}+\mathrm{Qtz}$ and $\mathrm{Grt}+\mathrm{W} \rightarrow \mathrm{St}+\mathrm{Chl}+\mathrm{Qtz}$. Chlorite associated with staurolite and garnet shows lower Mg\# (0.66-0.69) in comparison to that associated with garnet and kyanite $(\mathrm{Mg} \# 0.75)$. Garnet and staurolite show a decrease in $\mathrm{Mg \#}$ from the core ( $\mathrm{Mg} \# 0.26$ and 0.31 ) to the rim ( $\mathrm{Mg} \mathrm{\#} 0.22$ and 0.29 respectively) consistent with staurolite growth at the expense of garnet.

Since in the high-alumina metapelites staurolite does not coexist with biotite, the exhumation trajectory of the Kimi complex passed through the Grt-St-Chl stability field, recording a stage of rapid uplift and cooling (Fig. 3).

\section{DISCUSSION}

UHP terranes contain coesite and in some case, microdiamonds, and thus formed at pressures ranging from c. $2.5 \mathrm{GPa}$ to $>4 \mathrm{GPa}$ (Liou et al., 1998). These pressures cannot be achieved by simply stacking, schuppen style, slices of continental crust. Instead, crust must be subducted 100 to $>140 \mathrm{~km}$ into the upper mantle. By this process it results in a geometry where a wedge of mantle rocks lies directly above crustal rocks. It seems likely that mantle fragments could be transferred from the hanging wall to the footwall, perhaps as slices or ductile masses (Brueckner \& Medaris, 2000). Once intruded, the peridotite will share a common tectonothermal history with the host crustal rocks. At some stages, the conditions forcing the continental crust into the mantle are relaxed and the crust, with its cargo of peridotite bodies, will return towards the surface ("eduction"). Several mechanisms have been proposed to exhume deeply subducted crustal terranes (see references in Brueckner \& Medaris, 2000). Many of these models postulate that the crustal slab either delaminates from its underlying mantle or breaks off from the adjacent subducted oceanic lithosphere. In either case, the buoyancy of the crustal terrane relative to the enclosing mantle causes it to return towards the surface, presumably along detachment surfaces. Break-off of oceanic slab allows asthenosphere to well up into the mantle wedge and results in the intrusion of hot spinel peridotite that formed garnet by cooling (UHT subduction peridotite according to Brueckner \& Medaris, 2000). Garnet formed at the expense of spinel as a result of cooling either in the mantle during upwelling or within the subducted continental crust during intrusion or afterwards as the host slab was educted towards the surface. In the latter case, the garnet-bearing assemblages should give the same mineral ages as the host crustal rocks.

Figure 3 is a P-T-t diagram showing the exhumation paths of the crustal and mantle assemblages respectively from the UHP metamorphic Kimi complex, based on the petrological results obtained from amphibolitized 
eclogites, gneisses, high-alumina metapelites and pegmatites for the crustal assemblages and the peridotites/ pyroxenites for the mantle assemblages presented in the previous chapters. As it is shown in Fig. 3 the crustal and mantle assemblages followed separate exhumation paths up to a depth of about $60 \mathrm{Km}$ and subsequently both assemblages shared a common thermochronological history.

The inclusions of microdiamond in garnet porphyroblasts from the pelitic gneisses evidence subduction of sedimentary material from the Kimi complex to depths higher than $130 \mathrm{Km}$ ( $>4 \mathrm{GPa}$ ). Moreover, the exsolutions of silica rods in sodic garnet from the metapelites evidence subduction of the sedimentary rocks to depths of $\sim 220 \mathrm{Km}(\sim 7 \mathrm{GPa}$ ) (see Mposkos \& Kostopoulos, 2001). Available petrological data are not adequate to constrain the temperatures at the peak pressures conditions. However, the ubiquitous rutile exsolutions in garnet (titanium content in garnet is a temperature rather than pressure indicator) suggest temperatures higher than $1000{ }^{\circ} \mathrm{C}$ (Massonne, pers. comm., 2001).

Application of the Grt-Cpx Fe-Mg exchange thermometer (Ellis \& Green, 1979) on eclogites using garnet core-clinopyroxene core compositions yielded a temperature range of $780-830{ }^{\circ} \mathrm{C}$ for an assumed pressure of 1.5 $\mathrm{GPa}$. The same Grt-Cpx pairs yield temperatures between $945-995{ }^{\circ} \mathrm{C}$ for an assumed pressure of $7 \mathrm{GPa}$; temperatures that could be accepted as peak temperatures if we assume that exhumation occurred along the $\mathrm{Fe}-\mathrm{Mg}$ exchange equilibration curve i.e. with slight temperature decrease. Mineralogical and textural data that can put constraints on the exhumation path from the maximum depth $(\sim 220 \mathrm{Km}$ to $\sim 60 \mathrm{Km}$ are still lacking. The high enough temperatures that prevailed at shallow depths $\left(\sim 800^{\circ} \mathrm{C}\right.$ at $\left.1.5 \mathrm{GPa}\right)$ and the fact that the Kimi Complex stayed for a long time at appreciable depths (see below), forming the root of an overthickened crust, lead to extensive recrystallization/reequilibration and erased almost completely the mineral assemblages, formed at the previous stages. However, the mineral assemblages $\mathrm{Grt}+\mathrm{Kfs}+\mathrm{Pl}+\mathrm{Qtz}+\mathrm{Bt}$ and $\mathrm{Ms}+\mathrm{Grt}+\mathrm{Kfs}+\mathrm{Pl}+\mathrm{Qtz}$ in the migmatitic gneisses constrain the exhumation path at some stages between the reaction curves $\mathrm{Bt}+\mathrm{Ms}+\mathrm{Pl}+\mathrm{Qtz} \rightarrow \mathrm{Grt}+\mathrm{Kfs}+\mathrm{L}$ and $\mathrm{Ms}+\mathrm{Pl}+\mathrm{Qtz} \rightarrow \mathrm{As}+\mathrm{Kfs}+\mathrm{L}$ (i.e. between $800-850{ }^{\circ} \mathrm{C}$ for pressures $1.4-2 \mathrm{GPa}$ respectively, Le Breton \& Thomson, 1988, Fig. 3, Point B).

In garnet-spinel peridotite and spinel-garnet-clinopyroxenite the high $\mathrm{Al}_{2} \mathrm{O}_{3}$ content $(\sim 4.5-5.5 \%)$ in the primary clino- and orthopyroxene indicate high temperature protoliths. Temperature of $1235{ }^{\circ} \mathrm{C}$ and pressure of 2.6 GPa are calculated using the $\mathrm{Cr}$-in-Cpx barometer and the En-in-Cpx thermometer (Nimis \& Taylor, 2000) on the recalculated composition of a clinopyroxene containing spinel and orthopyroxene exsolutions (Plate 2C). High temperatures and pressures are also obtained $\left(1160-1240{ }^{\circ} \mathrm{C}, 2.4 \mathrm{GPa}\right)$ from the clinopyroxene composition coexisting with garnet in olivine-bearing clinopyroxenite. Such high temperatures at pressures of 2.4-2.6 GPa are not expected in an environment of a subducted plate nor at the base of the overlying lithospheric mantle wedge. The protolith of the Kimi ultramafic body represents, probably, a segment of the asthenosphere welled up into the mantle wedge as a result of break-off of the subducted oceanic slab from the continental slab carrying the Kimi crustal assemblage. The primary peridotite was possible a garnet peridotite, equilibrated at $\mathrm{P}>3 \mathrm{GPa}$ (Fig. 3, point A1) as indicate the spinel $2\left(\mathrm{X}_{\mathrm{cr}}^{\mathrm{spl2}}=0.14-0.15\right)$-pyroxene symplectite inclusions in spinel $1\left(\mathrm{X}_{\mathrm{cr}}^{\mathrm{spl}}=0.40-0.46\right)$ (Plate 2A). During asthenosphere upwelling and possibly with influx of water from the subducted plate, partial melting occurred. Continuing decompression and cooling occurred within the enlarged stability field of Cr-spinel peridotite (O'Neill, 1981) as suggest the spinel exsolutions in ortho- and clinopyroxene and the successive decrease of $\mathrm{Cr} /(\mathrm{Cr}+\mathrm{Al})$ ratio from the core to the rim in zoned $\mathrm{Cr}$-spinel grains $(0.46$ core $\rightarrow 0.20-0.15 \mathrm{rim}$, Fig.2). Crystallization of the melt and formation of cumulate pyroxenites occurred at high pressures $\left(\sim 2.4 \mathrm{GPa}-1240{ }^{\circ} \mathrm{C}\right.$, Fig. $\left.3, \mathrm{~A} 3\right)$ within the stability field of garnet-pyroxenite, indicated also by the garnet inclusions in Cpx 1 (plate $3 \mathrm{E}$ ). A subsequent increment of the exhumation path is characterized by isobaric cooling within the garnet-pyroxenite stability field as indicate the garnet exsolutions lamellae in Cpx 1 of pyroxenite (Plate 3B,C). For the garnet-spinel peridotite, this isobaric cooling occurred at the first stage within the spinel peridotite $\left(\mathrm{X}_{\mathrm{cr}}^{\mathrm{spl}}=0.10-0.15\right)$ stability field as indicate the spinel exsolution in ortho- and clinopyroxene (Plate 2B,C) and the ubiquitous matrix spinels, and subsequently passed into the spinel-garnet peridotite stability field as indicate garnet and spinel grains $\left(\mathrm{X}_{\mathrm{cr}}^{\mathrm{spl}}=\right.$ 0.08-0.14) preserved as inclusions in Opx2 (Plate 2E), hornblende (Plate 2F) and olivine associated with hornblende. Grt-Opx2 geobarometry (Brey \& Koehler, 1990) yielded a mean value of $1.5 \mathrm{GPa}$ for an assumed temperature of $800{ }^{\circ} \mathrm{C}$ (Fig. 3, B1). Grt-Cpx Fe-Mg exchange thermometry on Grt-Cpx pairs from the clinopyroxenites yielded equilibration temperatures of $820-825{ }^{\circ} \mathrm{C}$ for $\mathrm{Grt}\left(\right.$ core)-Cpx(core) compositions and $750-790{ }^{\circ} \mathrm{C}$ for Grt rim-Cpx rim and for exsolved Grt-Cpx host pairs at an assumed pressure of $1.5 \mathrm{GPa}$. These P-T values approximate those obtained for migmatite formation in gneisses of the continental assemblage. They possible represent the depth $(\sim 60 \mathrm{Km})$ of intrusion of the peridotite/pyroxenite assemblage into the continental assemblage. At this stage the migmatitic gneisses presumably contained still a melt component (Fig. 3,B). 


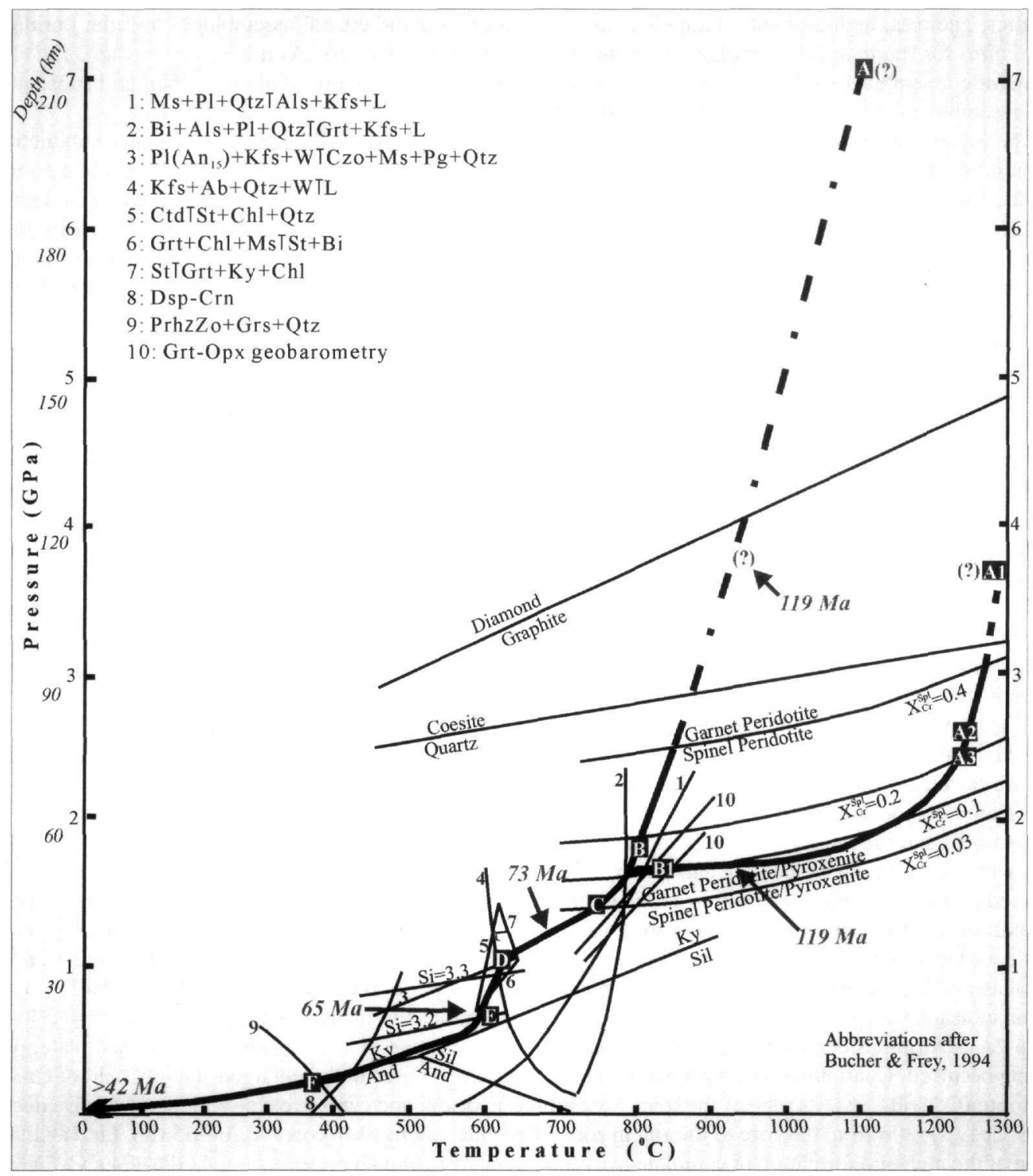

Figure 3: P-T-t diagram showing the exhumation path of the crustal assemblage $(A-B)$, the mantle assemblage (A1-B1) and their common path of exhumation (C-F) in the UHP metamorphic Kimi Complex (eastern Rhodope).

Subsequent sections of the exhumation path are well constrained from mineral assemblages and thermobarometric calculations for the amphibolitized eclogites, the high-alumina metapelites, the trondjemitic dyke in metagranodiorite and the muscovite pegmatites. Between points $\mathrm{C}$ and $\mathrm{D}$ in figure 3 the exhumation path is characterized by hydration reactions in both the crustal and mantle assemblages indicating influx of water. In peridotite the mineral assemblage $\mathrm{Ol}+\mathrm{Hbl}(\mathrm{Si}=6.5-6.8$ atoms p.f.u.) dominate and is formed by the reactions $\mathrm{Grt}+\mathrm{Cpx}+\mathrm{W} \rightarrow \mathrm{Ol}+\mathrm{Hbl}$ and $\mathrm{Opx}+\mathrm{Cpx}+\mathrm{Spl}+\mathrm{W} \rightarrow \mathrm{Ol}+\mathrm{Hbl}$, as indicate the garnet and spinel inclusions in hornblende (Plate 2F). In eclogites, kelyphitic and diablastic hornblende replaces garnet and clinopyroxene (Plate 4B). Garnet-hornblende thermometry (Graham \& Powell, 1984) yielded temperatures $670 \pm 40{ }^{\circ} \mathrm{C}$. The reaction $\mathrm{Ms}+\mathrm{Grt} \rightarrow \mathrm{Bt}\left(\mathrm{X}_{\mathrm{Mg}}=0.55\right)+\mathrm{Ky}(\mathrm{Ky} 2)+\mathrm{Qtz}$ occurred in high-alumina metapelites above the stability field of staurolite (Mposkos \& Liati, 1993). Point D records the crystallization of the trondjemitic dyke in the 
metagranodiorite (Plate 5A) at $1.05 \mathrm{GPa}$ and $630{ }^{\circ} \mathrm{C}$ (Johannes, 1986) determined from the textural relations and mineral assemblage $\mathrm{Ms} \pm \mathrm{Pg}+\mathrm{Pl}(\mathrm{An} 15-20)+\mathrm{Czo}+\mathrm{Qtz} \pm \mathrm{Ky}$ (Plate 5B,C). The mineral assemblage $\mathrm{Grt}+\mathrm{St}+\mathrm{Chl}$ in the kyanite-bearing high-alumina metapelites constrains the exhumation path within the stability field of $\mathrm{Grt}+\mathrm{St}+\mathrm{Chl}$ confined by the reaction curves 5,6 and 7 in figure 3 . Point $\mathrm{E}$ records the intrusion of muscovite pegmatites with muscovite having $3.2 \mathrm{Si}$ atoms p.f.u. The last point $\mathrm{F}$ on the exhumation path records the formation of diaspore, prehnite and chlorite (corundophyllite) replacing garnet and spinel, and tremolite, chlorite and prehnite replacing clinopyroxene and hornblende along fissures in the spinel-garnet-pyroxenites (Mposkos, 1994).

Geochronological data from the UHP metamorphic Kimi Complex are still few but adequate for recording the time of the (U)HP event and parts of the exhumation path. A Sm-Nd garnet-clinopyroxene-whole rock age of $119 \mathrm{Ma}$ from the spinel-garnet clinopyroxenite associated with the garnet-spinel peridotite is interpreted to record the HP/HT event (ca $1.6 \mathrm{GPa}$ at $770{ }^{\circ} \mathrm{C}$, Wawrzenitz \& Mposkos, 1997). In garnet clinopyroxenite REE are fractionated predominant between garnet and clinopyroxene, whereas HREE including Sm are preferentially incorporated in garnet. If we assume that the $\mathrm{Sm}$ and $\mathrm{Nd}$ contained in garnet are inherited from a preexistent phase, this phase was also garnet crystallized from the melt at HP-HT as indicate the garnet inclusions in HT clinopyroxenes (Plate 3C,E). In this case the age of $119 \mathrm{Ma}$ records no cooling stage at $\sim 1.6 \mathrm{GPa}$ and 770 ${ }^{0} \mathrm{C}$ but a previous stage of exhumation of the UHP event.

Gebauer \& Liati (1997) and Liati \& Gebauer (1999) report U-Pb SHRIMP ages from magmatic and metamorphic zircons from the Smigada eclogite of $119 \mathrm{Ma}$ and $73 \mathrm{Ma}$ respectively and characterized the same outcrop as grt-rich eclogite boudin. They interpret the zircon age of $119 \mathrm{Ma}$, which coincides with the Sm-Nd GrtCpx-whole rock age of the HP/UHT clinopyroxenite as crystallization age of the gabbroic oceanic protolith and that of $73 \mathrm{Ma}$ as the age of the HP metamorphism. Liati \& Gebauer (2001) have, recently, reinterpreted the age of $119 \mathrm{Ma}$, as crystallization age of magmatic zircons at UHP conditions, suggesting that the garnet-rich eclogite of Smigada represents an UHP mantle cumulate. The U-Pb zircon age of 119 Ma probably records an early stage of exkumation of the UHP event of the Kimi Complex, like the Sm-Nd Grt-Cpx-whole rock age.

The age of $73 \mathrm{Ma}$ from the metamorphic zircons presumably record the time of amphibolitization of the eclogite triggered by the influx of water. Liberation of zirconium from consumed garnet and clinopyroxene formed the metamorphic zircons at ca $670 \pm 40^{\circ} \mathrm{C}$ and 1.2-1.4 GPa.

The Rb-Sr muscovite age of $65 \mathrm{Ma}$ from an undeformed muscovite pegmatite, is interpreted as crystallization (thus intrusion) age (Mposkos \& Wawrzenitz, 1995) and constrains the P-T conditions of the Kimi complex at that time at $0.6 \mathrm{GPa}(20 \mathrm{~km})$ and $\sim 600{ }^{\circ} \mathrm{C}$. The Kimi Complex is exhumed to the earth surface before $42 \mathrm{Ma}$ as indicate the transgressively overlying Lutetian/Priabonian (48-42 Ma) conglomerates.

\section{CONCLUSIONS}

Structural, petrological and geochronological work has shown that the RMP is a complex of Alpine synmetamorphic nappe complexes, characterized by south- to southwest stacking and associated with both coeval and subsequent extension in an Alpine active margin setting. The Kimi Complex, representing the uppermost entity underwent UHP metamorphism in Lower Cretaceous ( $\geq 119 \mathrm{Ma}$ ). Pressures $>4$ GPa (probably $\sim 7$ $\mathrm{GPa}$ ) and temperatures $>1000{ }^{\circ} \mathrm{C}$ indicate subduction of oceanic and subsequent continental crustal material into the asthenospheric mantle under the European continental plate. Break-off of the subducted slab allowed asthenosphere to well up into the overlying mantle wedge and to undergo partial melting, possibly with influx of water from the subducted plate. The upwelling peridotite reequilibrated at pressures $<3 \mathrm{GPa}$ into the extended stability field of Cr-Spinel peridotite. Decompression and cooling occurred within the Cr-Spinel peridotite stability field up to $\sim 1.8 \mathrm{GPa}$ and $\sim 900^{\circ} \mathrm{C}$. Subsequent isobaric cooling crossed the stability field of garnet peridotite. At this stage peridotite intruded into the educted underlying continental crust. Exhumation of the subducted continental material was rather slow and lasted more than $\sim 55 \mathrm{Ma}$. Three stages of exhumation occurred. The first stage from the maximum depth of $\sim 200-220 \mathrm{Km}$ to $\sim 60 \mathrm{Km}\left(\mathrm{P} \sim 1.6 \mathrm{GPa}, \mathrm{T} \sim 800^{\circ} \mathrm{C}\right)$ is characterized by slow cooling rates, indicating rapid exhumation. At this stage significant overprinting of the earlier UHP assemblages occurred. The second stage of exhumation from $\sim 60 \mathrm{Km}$ to $\sim 38 \mathrm{~km}\left(\mathrm{P} \sim 1.05 \mathrm{GPa}, \mathrm{T} \sim 640{ }^{\circ} \mathrm{C}\right)$ is characterized by cooling at slow exhumation rates. At this stage, mineral assemblages in megaboudins of most rock types are characterized by static annealing reequilibation/recrystallization processes. The third stage of exhumation started between 73 and $65 \mathrm{Ma}$, is characterized by rapid uplift, influx of water (possibly released from the underlying slab carrying the Sidironeron and Kechros Complexes), intrusion of muscovite pegmatites at $\sim 20 \mathrm{Km}$ depths and finally rapid cooling at shallow depths until reaching the surface before 48-42 Ma. 


\section{AKNOWLEDGMENTS}

Dr. Alexander Krohe is gratefully acknowledged for endless, valuable discussion contributing significantly to the clarification of the tectonometamorphic evolution of Rhodope. Dr. D. Kostopoulos is cordially thanked for improving the style of the manuscript. Thanks should be, also, given to $\mathrm{PhD}$ student M. Perraki who calculated the PT conditions in peridotite applying the Cr-in-Cpx barometer and the enstatite-in-Cpx thermometer of Nimis \& Taylor and Al-in-Opx barometer of Brey and Koehler and constructed the figures and the plates.

*Tables with mineral compositions from garnet-spinel peridotites, spinel-garnet pyroxenites and eclogites are available from the author upon request.

\section{REFERENCES}

BARR, S.R., TEMPERLEY, S. \& TARNEY, J., 1999. Lateral growth of the continental crust through deep level subduction-accretion: a re-evaluation of central Greek Rhodope. Lithos, 46, 69-94.

BECKER, H., 1996. Geochemistry of garnet peridotite massifs from lower Austria and the composition of deep lithosphere beneath a Paleozoic convergent plate margin. Chemical Geology, 134, 49-65.

BIGAZZI, G., DEL MORO, A., INNOCENTI, G., KYRIAKOPOULOS, K., MANNETTI, P., PAPADOPOULOS, P., NORELLITI, P. \& MAGGANAS, A., 1989. The magmatic intrusion complex of Petrota, Western Thrace: Age and geodynamic significance. Geologica Rhodopica V.1, 290-297.

BREY, G.P. \& KÖHLER, T., 1990. Geothermobarometry in four-phase lherzolites II. New thermobarometers, and practical assessment of existing thermobarometers. J.Petrol. 31, 6, 1353-1378.

BRUECKNER, H.K. \& MEDARIS, L.G., 2000. A genetic model for the intrusion and evolution of mantle garnet peridotites in high-pressure and ultra-high-pressure metamorphic terranes. J.metamorphic Geol. 18, 123-133.

BUCHER, K. \& FREY, M., 1994. Petrogenesis of metamorphic rocks. Springer Verlag, 318 pages.

CHATTERJEE, N.D., KRÜGER, R., HALLER, G. \& OLBRIGHT, W., 1998. The Bayesian approach to an internally consistent thermodynamic database: theory, database, and generation of phase diagrams.

Contrib.Mineral.Petrol. 133, 149-168.

COLLERSON, K.D., HAPUGODA, S., KAMBER, B.S. \& WILLIAMS, Q., 2000. Rocks from the mantle transition zone: Majorite-bearing xenoliths from Malaita, southwest Pacific. Science, 288, 1215-1223.

DINTER, D.A., 1998. Late Cenozoic extension of the Alpine collisional orogen, northeastern Greece: Origin of the north Aegean basin. Geol.Soc.Am.Bull., 110, 1208-1230.

DOBRZHINESTKAYA, L.F., EIDE, E.A., LARSEN, R.B., STURT, B.A., TRONNES, R.G., SMITH, D.C., TAYLOR, W.R. and POSUKHOVA, T.V., 1995. Microdiamond in high-grade metamorphic rocks of the western gneiss region, Norway. Geology, 23: 597-600.

ELLIS, D.S. \& GREEN, D.H., 1979. An experimental study of the effect of Ca upon garnet-clinopyroxene Fe-Mg exchange equilibria. Contrib.Mineral.Petrol. 71, 13-22.

EVANS, B.W., 1982. Amphiboles in metamorphosed ultramafic rocks. In Reviews in mineralogy V.9B. Min.Soc.Amer. p.98-112.

FERRY, J.M. \& SPEAR, F.S., 1978. Experimental calibration of the partitioning of Fe and $\mathrm{Mg}$ between biotite and garnet. Contrib.Mineral.Petrol. 66, 113-117.

GEBAUER, D. \& LIATI, A., 1997. Geochronological evidence for mesozoic rifting and oceanisation followed by Eocene subduction in the Rhodope complex (northern Greece). Terra Nova Abstract. Suppl. 7, 10-11.

GASPARIK, T., 1984. Two-pyroxene thermobarometry with new experimental data in the system CaO-MgO$\mathrm{Al}_{2} \mathrm{O}_{3}-\mathrm{SiO}_{2}$. Contrib.Mineral.Petrol. 87, 87-97.

GRAHAM, C.M. \& POWELL, R., 1984. A garnet-hornblende geothermometer: calibrtion, testing and application to the Pelona schists, Southern California. J.Metamorphic Geol. 2, 13-21.

HEMINGWAY, B.S., BOHLEN, S.R, HANKINS, W.B, WESTRUM, Jr E.F. \& KUSKOV, O.L., 1998. Heat capacity and thermodynamic properties for coesite and jadeite, reexamination of the quartz-coesite equilibrium boudary. Am.Mineral. 83: 409-418.

JENKINS, D.M. \& NEWTON, R.C., 1979. Experimental determination of the spinel peridotite to garnet peridotite inversion at $900^{\circ} \mathrm{C}$ and $1,000^{\circ} \mathrm{C}$ in the system $\mathrm{CaO}-\mathrm{MgO}-\mathrm{Al}_{2} \mathrm{O}_{3}-\mathrm{SiO}_{2}$, and at $900^{\circ} \mathrm{C}$ with natural garnet and olivine. Contrib.Mineral.Petrol. 68, 407-419.

JOHANNES, W., 1995. The sidnificance of experimental studies for the formation of migmatites. In Ashworth (ed.) Migmatites, 36-85, Blackie, New York.

KOSTOPOULOS, D., IOANNIDIS, N. and SKLAVOUNOS, S., 2000. A new occurrence of ultrahigh-pressure 
metamorphism, Central Macedonia, northern Greece: Evidence from graphitised diamonds? Int.Geol.Rev., 42, 545-554.

KOZIOL \& NEYTON, 1988. Redetermination of the garnet breakdown reaction and improvement of the plagioclase-garnet- $\mathrm{Al}_{2} \mathrm{SiO}_{5}$-quartz geobarometer. Am.Mineral. 73:216-223.

KROHE, A. \& MPOSKOS, E., 2001. Structural evolution and exhumation history of the Rhodope UHP-HP metamorphic province (Northern Greece). Bull. Geol.Soc.Greece (V.XXXIV, 1, 75-82).

LE BRETON, N. \& THOMPSON, A., 1988. Fluid-absent (dehydration) melting of biotite in metapelites in the early stages of crustal anatexis. Contrib. Mineral. Petrol. 99:226-237.

LIATI, A. \& GEBAUER, D., 1999: Constraining the prograde and retrograde P-T-t path of Eocene HP rocks by SHRIMP dating of different zircon domains: inferred rates of heating, burial, cooling and exhumation for central Rhodope, northern Greece. Contrib. Mineral. Petrol. 135, 340-354.

LIATI, A. \& GEBAUER, D., 2001. Palaeozoic as well as Mesozoic sedimentation and polymetamorphism in Central Rhodope (N. Greece) as iferred from U-Pb SHRIMP-dating of detrital zircons. EUG XI Symposium LS03, 315.

LIATI, A. \& GEBAUER, D., 2001. Garnet-rich rocks recording UHP conditions in Northern Greece (Eastern Rhodope Zone). Proceedings of UHPM Workshop 2001 at Waseda University, 275-278.

LIOU, J.G., ZHANG, R.Y., ERNST, W.G., RUMBLE, D. \& MARUYAMA, S., 1998. High-pressure minerals from deeply subducted metamorphic rocks. In Reviews in Mineralogy, V.37, pp.33-96.

MASSONNE, H.J., 1998. A new occurrence of microdiamonds in quartzofeldspathic rocks of the Saxonian Erzgebiege, Germany and their metamorphic evolution. In Gurney, J.J., Gurney, J.L., Pascoe, M.D. and Richardson, S.H. (eds). Proc. Vii ${ }^{\text {th }}$ In. Kimb.Conf. The P.H.Nixon Volume. 2, 533-539.

MPOSKOS, E., 1994. Interpretation of metamorphic paths of the lower and upper tectonic unite of Rhodope: Similarities and differences. Bull.Geol.Soc.Greece (In Greek with English abstract). V. 31/1, 255-269.

MPOSKOS, E. \& LIATI, A., 1993. Metamorphic evolution of metapelites in the high-pressure terrane of the Rhodope zone, Northern Greece. Can.Mineral. 31, 401-424.

MPOSKOS, E. \& WAWRZENITZ, N., 1995. Metapegmatites and pegmatites bracketing the time of HP-metamorphism in polymetamorphic rocks of the E-Rhodope, N.Greece: Petrological and geochronological constraints. Geol.Soc.Greece. Special Publ. 4/2, 602-608.

MPOSKOS, E. \& KROHE, A., 2000. Petrological and structural evolution of continental high pressure (HP) metamorphic rocks in the Alpine Rhodope Domain (N.Greece). In: Panayides, I., Xenophontos, C. and Malpas, J., (eds), Proc. $3^{\text {rd }}$ Int.Conf.Geol. E.Mediterranean, Nicosia, Cyprus, 221-232.

MPOSKOS, E. \& KOSTOPOULOS, D., 2001. Diamond, former coesite and supersilicic garnet in metasedimentary rocks from the Greek Rhodope: a new ultrahigh - pressure metamorphic province established. LPSL, 192, 497-506

MPOSKOS, E., KOSTOPOULOS, D. \& KROHE, A., 2001. Ultrahigh-pressure metamorphism from the Rhodope metamorphic province, Northern Greece: A preliminary report on a new discovery. EUG XI, Symposium, LS06, 341.

NIMIS, P. \& TAYLOR, W.R., 2000. Single clinopyroxene thermobarometry for garnet peridotites. Part I. Calibration and testing of a Cr-in-Cpx barometer and enstatite-in-Cpx thermometer. Contrib. Mineral. Petrol. 139, 541-554.

O' NEILL, H., 1981. The transition between spinel lherzolite and garnet lherzolite and its use as a geobarometer. Contrib.Mineral.Petrol. 77, 185-194.

RICOU, L.E., BURG, J.P., GODFRIAUX, I. \& IVANOV, Z., 1998. Rhodope and Vardar: the metamorphic and the olistostromic paired belts related to the Cretaceous subduction under Europe. Geodinamica Acta, 11, 285309.

SOBOLEV, N.V. \& SHATSKY, V.S., 1990. Diamond inclusions in garnets from metamorphic rocks. Nature $343:$ 742-746.

TSIKOURAS, B., PE-PIPER, G. \& HATZIPANAGIOTOU, K., 1990. A new date for an ophiolite of the western margin of the Vardar Zone, Samothraki, Greece. N. Jb. Miner. Mh, 11, 512-527.

VUICHARD, J.P. \& BALLEVRE, M., 1988. Garnet-chloritoid equilibria in eclogitic pelitic rocks from Sezia Zone (Western Alps): their bearing on phase relations in high pressure metapelites. J. Metamorphic Geol., 6, $135-157$.

WAWRZENITZ, N. \& MPOSKOS, E., 1997. First evidence for Lower Cretaceous HP/HT -metamorphism in the Eastern Rhodope, North Aegean Region, North-East Greece. Eur. J. Mineral., 9, 659-664.

WAWRZENITZ, N. \& KROHE, A., 1998. Exhumation and doming of the Thasos metamorphic core complex 
(S.Rhodope, Greece): Structural and geochronological constraints. Tectonophysics, 285, 301-332.

XU, S., OKAY, AI, JI, S., SENGOR, AMC, SU, W., LIU, Y \& JIANG, L., 1992. Diamond from the Dabie Shan metamorphic rocks and its implication for tectonic setting. Science 256: 80-82.

YE, K., CONG, B. \& YE, D., 2000. The possible subduction of continental material to depths greater than 200 Km. Nature, 407, 734-736. 